\title{
Spatial structure, intra-urban commuting patterns and travel mode choice: Analyses of relationships in the Kumasi Metropolis, Ghana
}

DOI:

10.1016/j.cities.2019.102432

\section{Document Version}

Accepted author manuscript

Link to publication record in Manchester Research Explorer

Citation for published version (APA):

Acheampong, R. A. (2019). Spatial structure, intra-urban commuting patterns and travel mode choice: Analyses of relationships in the Kumasi Metropolis, Ghana. Cities, 96, [102432]. https://doi.org/10.1016/j.cities.2019.102432

\section{Published in:}

Cities

\section{Citing this paper}

Please note that where the full-text provided on Manchester Research Explorer is the Author Accepted Manuscript or Proof version this may differ from the final Published version. If citing, it is advised that you check and use the publisher's definitive version.

\section{General rights}

Copyright and moral rights for the publications made accessible in the Research Explorer are retained by the authors and/or other copyright owners and it is a condition of accessing publications that users recognise and abide by the legal requirements associated with these rights.

\section{Takedown policy}

If you believe that this document breaches copyright please refer to the University of Manchester's Takedown Procedures [http://man.ac.uk/04Y6Bo] or contact uml.scholarlycommunications@manchester.ac.uk providing relevant details, so we can investigate your claim.

\section{OPEN ACCESS}




\title{
Spatial structure, intra-urban commuting patterns and mode choice: Analyses of relationships in the Kumasi Metropolis, Ghana
}

\author{
Ransford A. Acheampong \\ Department of planning and environmental management, Manchester Urban Institute, \\ University of Manchester \\ Email: ransfordantwi.acheampong@manchester.ac.uk
}

This is the author's version of the original article published in Cities

Accepted 7 August 2019

\begin{abstract}
Commuting patterns in Sub-Saharan African cities are evolving in tandem with rapid levels of historical urbanization. Yet, our understanding of how the prevailing urban spatial structures shape travel patterns is limited. This study explores the land-use-travel nexus in the Kumasi metropolis in Ghana, by focusing on work commuting. It uses newly available land-use datasets to present TAZ-level analysis of the distribution of land-use activity types. From a survey of a representative sample of 1,158 workers, the characteristics of commuters and their travel patterns are examined. The analyses reveal a unique structure for the urban system, that is polycentric in both morphological and functional dimensions, but with a relatively stronger centre (i.e. CBD). Overall, home-work commute flows strongly reflect the prevailing spatial structure. Residence in suburban neighbourhoods; non-home-based employment locations; home-work distance exceeding $0.3 \mathrm{~km}$; and relatively higher-incomes influence motorized transport choice and car-use for work journeys. Walking to work is strongly associated with lower-income levels, residence in historical-core neighbourhoods and home-based employment. The paper contributes to conceptualizing, theorising and understanding the spatial structuretravel nexus at the intra-urban scale by focusing on a previously unexplored urban context. The implications of the findings for integrated urban development and transportation planning are highlighted.
\end{abstract}

Key words: land use; spatial structure; travel behaviour; work commutes; mobility patterns; Ghana 


\section{Introduction}

Individuals' travel behaviours and the emergent patterns of spatial interaction in cities in the Global South are undergoing changes. In many of these cities, growing levels of motorization, congestion, longer commuting times, and increasing emission of $\mathrm{CO}_{2}$ typify the urban transportation situation (Agyemang, 2017; Sietchiping et al., 2012; Armah et al., 2010; Zhao, 2010). In part, these changes have been attributed to rising incomes on the one hand, and the inferior quality of existing public transport services on the other hand, which induces vehicular ownership and car use. Increasing investment in the development of transport infrastructure also continues to induce additional levels of motorization (Cervero, 2013; Kutzbach, 2009; Adarkwa and Poku-Boansi, 2011). A more fundamental reason, aside from the aforementioned, is the unprecedented levels of historical urbanization that has occurred over the last seven decades in countries in the Global South. One of the profound impacts of historical urbanization has been the expansion of the physical size of cities, often characterised by lateral growth, sprawl and fragmented spatial development (Stow et al., 2013; Angel et al. 2012). The resulting spatial structures, in turn, increases the separation between various land use activities, such as the place of residence and the place of work, and shapes commuting flows.

Indeed, the notion that urban spatial structure shapes travel behaviour and mobility patterns is now well-established empirically. Urban spatial structure is a multi-scalar concept, which is used in both morphological and functional terms, to describe the spatial configuration and linkages between different activity nodes within an urban area or a city-region (Muñiz and Garcia-López, 2019; Zhong, et al., 2017; Vasanen, 2012). Within an urban system, the concept also reflects the composition and distribution of different land use activities, such as the workplace, place of residence and shopping, as well as the distance separations between any combinations of these activities. Physical distance, in turn, creates the need for travel, which may be observed and measured in various aspects, including trip purpose and frequency, trip origin and destination, mode choice for the trip and travel costs (Moeckel et al., 2018; Acheampong and Silva, 2015; Wegner and Fürst, 2004)

The nexus between urban structure and patterns of spatial interaction could, therefore, be observed and analysed at different spatial scales. In a polycentric urban system, this nexus could be observed as daily flows of commuting that occur between a network of adjacent centres either within a single urban area or an urban-region (Sarkar et al., 2018; Zhong, et al., 2017). At another scale, broad urban zones, and aggregate Traffic Analysis Zones (TAZs), which reflect the distribution of population and land use activities for travel demand modelling, provide the spatial anchors for understanding the underlying influence of spatial structure on travel demand in urban areas (Zhang et al., 2011; Martinez et al., 2007). Moreover, at the neighbourhood scale, urban spatial structure variables, including land use density and diversity, destination distance, 
street density and connectivity have been found to influence different aspects of travel behaviour and the associated energy use and environmental impacts (Choi, 2018; Ding et al., 2017b; Næss, 2013; Cervero and Murakami, 2010).

The extent to which urban spatial structure influences mobility patterns and travel choices has been extensively studied in cities in developed countries (see e.g. Næss, 2013; Erwing and Cervero, 2010) and gained attention in recent years in emerging economies, especially China (see e.g. Zhang et al., 2019; Yang and Cao, 2018; Ding et al., 2017b; Zhao 2010; Wang et al., 2011). Yet, in developing countries, where rapid population growth is having profound impact on urban form, our understanding of the emergent spatial structures and commuting patterns, is rather limited. This is particularly so in the context of Sub-Saharan African cities, where only a handful of empirical research has explored the subject in recent years (see e.g. Gorham, 2017; Asikhia and Nkeki, 2013; Venter et al., 2007). This paper, therefore, contributes to the emerging scholarship on the topic in developing countries, by exploring the urban spatial structurecommuting nexus in the Kumasi Metropolis, the second largest metropolitan area in Ghana, West Africa. In recent years, few studies have sought to understand travel mode choice, as one aspect of travel behaviour in urban areas in Ghana (see e.g. Acheampong, 2019a; Agyemang, 2017; Esson et al., 2016; Amoh-Gyimah and Aidoo, 2013; Abane, 2011). Despite the valuable scientific contributions of these works, they neither characterise the existing urban structure nor explicitly capture its role in shaping mode choice and overall mobility patterns. This paper, therefore, overcomes these limitations by drawing on newly available land use datasets and a survey of the home-work travel decisions of 1,158 individuals in the Kumasi Metropolis, to explore the relationships between urban structure and mobility patterns.

The current paper makes theoretical contributions and provide empirical insights that could inform integrated spatial development and transport policy and planning. From a theoretical perspective, the analyses presented in this paper have made it possible, for the first time, to characterise at the intra-urban scale, the prevailing spatial structure of case study metropolis in both morphological and functional terms. Based on the analysis of commuting flows, the study identifies a unique structure for the urban system that is not necessarily mono-centric, but rather polycentric and hierarchical in both morphological and functional sense, with a relatively stronger centre (i.e. CBD). The policy implications of the observed patterns of mobility that are generated within this spatial context, and other important aspects of commuting such as travel mode choice and commuter characteristics, are highlighted.

The rest of the paper is structured as follows: Following the introduction section, a review of previous research is presented in section two. Section three focuses on the research methodology, which covers a background description of the case study area and data sources; 
questionnaire design and data collection. Results of the data are presented in section four, followed by a discussion of the main research findings, their policy implications and concluding remarks in sections five, six and seven, respectively.

\section{Conceptualising urban spatial structure}

Urban spatial structure as a concept carries both morphological and functional connotations. From this understanding, a monocentric urban structure reflects an urban system with a strong concentration of economic activities and jobs in the city centre. In a monocentric configuration, travel patterns that emerge from the prevailing structure and reflect how the dominant centre is functionally connected to other parts of the city, tend to exhibit a radial pattern (Schwanen et al., 2001). While the monocentric configuration has traditionally provided the theoretical basis for urban land use and travel analysis based on the access-space-trade-off assumptions (e.g. Alonso, 1964), its suitability for exploring the evolving spatial configuration of urban system has waned over the years (Kloosterman and Musterd, 2001). Indeed, urban systems do evolve into complex patterns in which the emergent commuting flows no longer follow the traditional monocentric pattern, but rather exhibit a polycentric configuration whereby within the same system, several adjacent centres exist (Vasanen, 2012).

While polycentricity has become a popular framework for characterising urban spatial structure and the accompanying travel patterns, defining the term is not straightforward. As Vasanen (2012) notes, when used in the morphological sense, polycentricity can refer to a form of spatial organization where several adjacent centres are in the same urban system. This morphological connotation, however, obscures the fact that polycentricity can be conceptualized and delineated at different spatial scales (Hall and Pain, 2006; Taylor et al., 2006). The multi-scale approach highlights the functional dimension of polycentricity by focusing on the linkages between different centres such as the daily commute-flows or the strength of business networks (see e.g. Hincks et al., 2018; Zhong, et al., 2017). From this multi-scalar perspective, polycentric spatial structure could be characterised as being 'intra-urban', 'inter-urban' and 'inter-regional' (see Vasanen, 2012; Garcia-Lo'pez and Mun iz, 2010; Yue et al., 2010; Lang and Knox, 2009; Meijers, 2008; Hall and Pain, 2006; Davoudi, 2003; Laan, 1998).

An intra-urban polycentric spatial structure can be observed as a clustering of population or employment within a metropolitan area or a functional urban region (Vasanen, 2012). The intraurban structure allows to study the functional linkages among adjacent centres in the same urban system. However, the primary focus of this approach on the clustering of economic activities implies that it pays much less attention to the distribution of the residential population that depend on these activities. In view of this the intra-urban scale definition of polycentricity may not serve all analytical purposes, especially when it comes to examining travel behaviours beyond 
trip origins and destinations. For this reason, some studies of the nexus between spatial structure and travel behaviour adopt different spatial scales of analysis, such as differentiating between the historical-core and inner-suburban and outer-suburban zones within the same metropolis (see e.g. Næss, 2013; Ewing and Cervero, 2010; Maat and Timmermans, 2009; van Eck et al., 2005). In these studies, the historical-core zone is delineated as the area within the metropolis that marks the origins of historical growth. As such, historical-core areas tend to coincide with the boundaries of the central business district or the main centre of the metropolis. The suburban zones on the other hand, reflect relatively new, dominantly residential areas which are often served by their own sub-centres.

Moreover, for purposes of travel demand analysis in the traditional four-step travel demand model and spatial interaction models, several aggregate zones are delineated within the same metropolis (see Acheampong and Silva, 2015; Bates 2000; McNally, 2000). These zones, referred to as Traffic Analysis Zones (TAZs) are defined based on socio-economic, demographic and landuse characteristics to provide the spatial anchors for examining trip production and attraction patterns (see e.g. Zhang et al., 2011; Martinez et al., 2007). The land use structure within each TAZ reflects the configuration of activities such as employment and residence, and the transport networks linking them. Trip origin and destinations observed at any time between two TAZs, therefore, reflect the amount of spatial interaction between them, which is often expressed as a function of the number of activities within each zone accounting for impedance, such as the distance or time it takes to move between zones (Kerkman et al., 2017; Batty, 2013).

\subsection{The relationship between urban spatial structure and travel behaviour}

Different urban spatial structures shape travel patterns and travel behaviour in diverse ways. In polycentric spatial configurations, the relevant spatial structure variables that influence travel behaviour include distance to the main CBD, distance to the closest sub-centre and distance to main transport infrastructure (see e.g. Muñiz and Garcia-López, 2019). Previous evidence shows that polycentricism reduces commuting distance and commuting times, and travel-related energy use and emissions, due to the existence of alternative centres to the CBD (Muñiz and Garcia-López, 2019; Asikhia and Nkeki, 2013, Muñiz et al., 2013; Zhao et al., 2011; Næss, 2007).

Several studies have also investigated the causal mechanisms by which urban form or urban built environment characteristics influence travel behaviour and travel-related energy consumption and $\mathrm{CO}_{2}$ emissions (e.g. Yang and Cao, 2018; Ding et al., 2017a; Næss, 2013; Aditjandra et al., 2013; Ewing and Cervero, 2010). These studies integrate built-environment/urban structural characteristics and behavioural attributes of households and individuals. The built environment characteristics include density, land use mix, home-employment balance, neighbourhood design, street network connectivity, destination accessibility and distance to transit. The behavioural 
component addresses households and individuals' characteristics such as income, gender, professional status, life-cycle stage, attitudes, beliefs and perceptions.

The evidence suggest that urban structural variables have considerable influence on travel behaviour. Generally, increasing travel distance between activity locations increases the likelihood of travel by car (Manaugh et al., 2010). Populations living in sub-urban areas, where densities tend to be relatively low and locations are accessible within an available time budget when travelling by car, tend to travel longer distances using motorized forms of transportation (van Eck et al., 2005). On the contrary, people living in dense traditional neighbourhoods travel relatively shorter distances and tend to use walking, cycling and public transit (Næss, 2013; Ewing and Cervero, 2010; Maat and Timmermans, 2009).

From a behavioural point of view, urban commuting encompasses many aspects, including trip purpose and frequency, trip origins and destinations, travel mode choice, route choice, travel distance, travel time and transport costs. With respect to trip purpose, work travel constitutes one of the dominant purposes of individuals' daily commute in urban areas, hence understanding home-work travel patterns and associated decisions, including mode choice have been major themes in urban transportation research. Despite having been extensively studied, a survey of the literature shows that there is not a single, all-encompassing theoretical framework for studying travel mode choice. Whereas some studies adopt utility theory (e.g. De Vos et al., 2016; Rasouli and Timmermans, 2014), others draw on socio-psychological and ecological frameworks to understand the influence on travel mode choice of a range of behavioural factors (e.g. Vij et al., 2014; Paulssen et al., 2014).

While the theoretical basis and assumptions of the different approaches may not be the same, they fundamentally attempt to capture individuals' expectations of the outcomes of using a particular mode of transport to satisfy a given travel need. The decision utility associated with prospective choice of travel mode alternatives could be conceptualized partly as function of instrumental utilitarian benefits, such as comfort, travel speed, flexibility, privacy and affordability that the individual associates with each alternative (De Vos et al., 2016). The time spent travelling and travel time use while travelling constitute key factors influencing individuals' travel mode choice decisions (Frank et al., 2008; Hamed and Olaywah, 2000). Consequently, all other things being equal, individuals would choose the fastest travel option to work. Perceptions of travel speed associated with different modes may vary among individuals under certain circumstances. For example, individuals having their work within the immediate vicinity of the dwelling would consider walking or cycling as the fastest and most suitable mode of travel. Similarly, in suburban areas where public transit is not easily accessible, access time from home to the nearest stop and waiting times could be significantly higher, thereby increasing total travel 
time. In such situations, the need to get to destinations faster could be a major motivation for car ownership and use.

Given their income constraints, low-income and urban poor households look for cheaper travel options to minimize expenditure on travel to be able to meet other non-travel related expenditures such as housing, shopping and health. Consequently, in some contexts, such as in cities in Ghana, low-income and urban poor workers tend to engage in home-based work or conduct economic activities within the immediate vicinity of their dwelling where the shorter distance means that they could either walk or travel shorter distances using available cheaper public transit services (Jain and Tiwari, 2019; Acheampong, 2018). Equally important travel mode choice decision utility factors are the need for flexibility, comfort and privacy while traveling to work. In urban areas in Ghana, for example, the trotro system (10-19-seater mini-buses) provides a relatively flexible means of inter- and intra-city travel by allowing passengers to embark and disembark at locations of their choice, although doing so is illegal (Esson et al., 2016). Yet, poor vehicle conditions, lax safety standards and overcrowding of the existing public transit services (Birago et al., 2017; Amoh-Gyimah and Aidoo, 2013) imply that individuals' expectations of comfort and privacy are not met. Consequently, households and individuals of higher socioeconomic means, dissatisfied with inferior quality of public transit choose to commute to work in their own cars (Acheampong and Siiba, 2019).

In the next section, the methodology employed to explore the various aspects of the home-workcommuting-nexus in the Kumasi Metropolis, including work trip origins and destinations among TAZs, work travel mode choice and travel costs is presented. The discussion covers data sources, questionnaire design, sampling strategy and questionnaire administration.

\section{Methodology}

\subsection{Case study area and data sources}

Empirical work for this study was undertaken in the Kumasi Metropolitan Area (KMA), in Ghana, West Africa. With a population of about two million individuals living in some four hundred and fifty thousand households (Ghana Statistical Services, 2013), the KMA is the second largest metropolis in Ghana, after the Accra Metropolitan Area. Over a 28-year period from 1986 to 2014 , the metropolis experienced about a three-fold increase in its built-up land from $51 \mathrm{~km}^{2}$ to $177.501 \mathrm{~km}^{2}$ at an average annual expansion rate of $4.5 \%$ (Acheampong, 2019b). At this rate of urban expansion, typified by sprawl, the size of the built-up area of the metropolis has changed significantly, affecting the spatial distribution of land use activities, such as the balance between the place of residence and place of work, as well as the associated daily mobility patterns and individual's travel choices. 
The study uses data from two main sources. From the Town and Country Planning Department, detailed land use data covering the entire metropolis was obtained. The dataset contains different land use types, including residential, commercial, industrial, educational and mixedresidential and commercial uses at parcel level. Accurate land use data at this resolution has not been available in the past, and as such, this research is the first to make use of the detailed land use data to explain patterns of spatial interaction in relation to home-work travel in the metropolis. Data in the form of analogue maps of designated TAZs of the metropolis were also obtained from the Department of Urban roads and converted into digital format for use in this study. The second source of data is a cross-sectional survey of home-work travel patterns conducted in the metropolis. The survey process, covering questionnaire design, sampling strategy and questionnaire administration, is presented in the sections below.

\subsection{Questionnaire design}

A structured questionnaire was designed to collect data covering a range of variables. The survey questionnaire was designed to elicit data that pertains to the household as unit as well as individual workers within the household. The rationale for this is that the resulting data on specific aspects of an individual's travel choices, namely travel mode choice and travel costs, would be analysed and interpreted within the broader context of attributes defining their respective households. The survey questionnaire covered three main themes relevant to the study, which are briefly outlined as follows:

The first theme of the questionnaire comprised questions used to elicit data on the background socio-demographic characteristics of the households. Data on relevant variables, including income, household size, educational attainments of household members, marital status, employment, and number of working members in the household were obtained. The second theme of the survey questionnaire focused on the home-work employment combinations all adult working individuals in the household. In the questionnaire, an individual's employment location would first be differentiated as being either non-home-based or home-based (i.e. located in the home and/or located not more than $100 \mathrm{~m}(0.1 \mathrm{~km})$ within the immediate vicinity of the home). Each individual respondent would also state the name of the locality where their job is located. With the locality of residence and employment locations known from the survey, work trip origin and destination for an individual could be allocated to the appropriate TAZ to derive trip production and distribution patterns later at the analysis stage.

The final theme of the survey questionnaire comprised questions that were formulated to obtain additional information about individuals' work travel. Under this theme, data on work travel mode choice was obtained. In the questionnaire, all travel modes in the metropolis were 
identified. Each respondent would indicate their primary mode ${ }^{1}$ of transport for each day's work journey for a five-day period preceding the day of the interview. To better understand individual's work travel mode choices, each worker was asked to indicate the importance they attached to a set of five decision utility factors, namely affordability, comfort, privacy, flexibility and travel time (i.e. mode that is perceived to offer the quickest travel time). These factors were chosen following a thorough review of the existing literature because they capture mode- and service-specific attributes and allow the respondents to provide subjective evaluations for them in relation to their daily travel mode choices. Individuals also indicated the time of day ${ }^{2}$ work travel from the home and vice versa occurred, and the departure and arrival times of those journeys, for the most recent work trip undertaken prior to the day of the interview. Finally, each individual worker indicated their weekly out-of-pocket work travel spending.

\subsection{Data collection: sampling strategy and questionnaire administration}

A representative sample of 1,158 individual workers from 665 households, distributed across the historical-core, inner-suburban and outer-suburban zones of the metropolis were interviewed. The study respondents were recruited using a multi-scale sampling approach that considers the three broadly defined urban zones (i.e. historical-core, inner-suburban and outer-suburban) and population distribution at the settlement level in each zone (see Acheampong, 2018). Based on the total number of households in the Metropolis (i.e. 436,691), a minimum representative sample size of 665 households was determined at $99 \%$ confidence level. The target sample of households were distributed proportionately among the nine sub-metropolitan units in the metropolis, based on their share of the total number of households. Ultimately, respondents were selected from 32 proxy locations, representing the major settlements in terms of population size in 20 spatial strata across the metropolis. The total sample of households interviewed in each of the proxy settlements is based on the selected settlement's share of households to that of their respective sub-metros. Detailed information about the sample distribution can be found in Table 1 in the appendix section. Fig 1 shows the distribution of the sample of households and individuals interviewed for this study within the three urban zones and 20 spatial units of sampling.

\footnotetext{
${ }^{1}$ Primary mode was explained to the respondents as the mode used for a significant segment of the work journey. For instance, if a person walked for 5 minutes to the nearest stop before catching a public transport to work, then that person would indicate the latter instead of the former as the main mode of transport.

2 Options were presented starting from 'before 6am' to 'after 9am' in a 25-minute interval for morning home-to-work trips, and 'before 3:30pm' and 'after 6:30pm' in a 25-minute interval for evening work-to-home trips.
} 


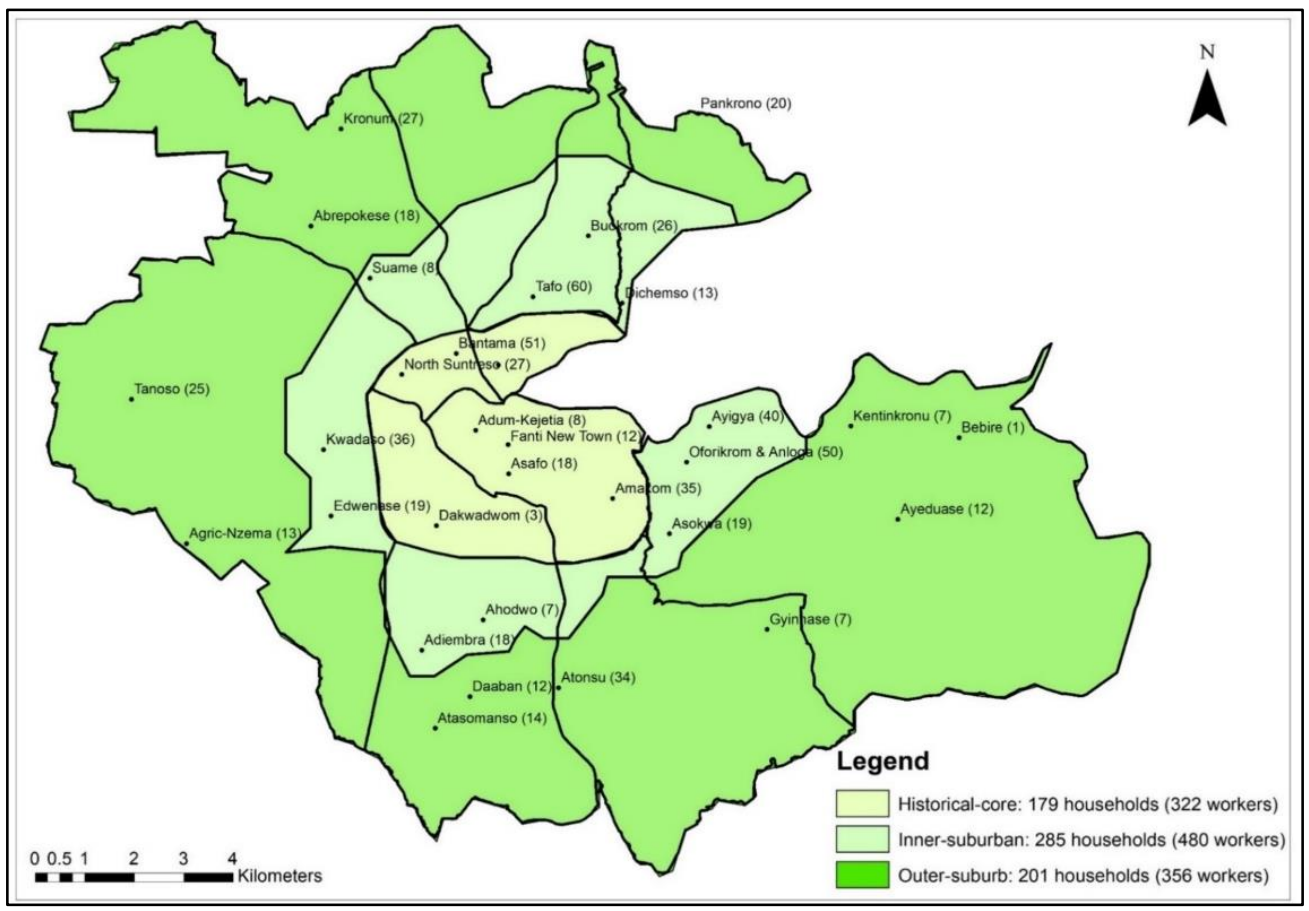

Fig 1: Distribution of sampled households according to 32 proxy locations and urban-zones in the study area

Houses were first randomly selected at the study locations from which a household was identified and approached to be interviewed. In selecting a household to interview, the interviewers encountered a number of scenarios of which the major ones are explained as follows: Firstly, where there were multiple households living in the same house, as is the case in the traditional compound dwelling, one household was randomly selected and interviewed. In one scenario, this would be the household available at home as of the time of the visit and was willing to participate in the study. In another, the interviewer would randomly approach one of the households first, explain the purpose of the study and if they agreed to participate, interview that household. If they declined, the interviewer would move to the next available household in the same house and follow the same protocol outlined above. All individual working members within the selected household, aged 15 years and above, were interviewed about their home-work travel characteristics. In instances where at least one of the working members of the household was not available, the interviewer would arrange another day and time and return to complete the interviews. In most cases, a minimum of two visits were required to complete an interview with a selected household. Ultimately, a total of 179 households and their 322 workers (representing $28 \%$ of all workers interviewed); 285 households and their 480 workers (representing $41 \%$ of all workers interviewed); and 201 households and their 356 workers (representing 31\% of all workers interviewed), were interviewed from the historical-core, inner-suburban and outersuburban zones of the study area, respectively. 


\subsection{Statistical analyses}

Descriptive summary statistics have been used throughout the paper in presenting the results of the analysis of both the survey and land use distribution data. In addition to this, a series of logistic regression models are specified to examine the determinants of work travel mode choice. Grounded in Random Utility Theory, logistic regression analysis allows to model the probability of choice among discrete alternatives, as a function of several relevant explanatory variables (Bowman and Ben-Akiva, 2001; McFadden, 1987). In this study, binary logit models are specified to examine the determinants of travel mode choice for dichotomous outcome variables (i.e. choice between car-use and other modes; and choice between walking and motorized forms of transportation). A multinomial logit model is also specified for a polychotomous mode choice outcome variable that examines the probability of choice between walking, public transport minibus/trotro and taxi-see section 4.3.

The binary logistic equation takes the form:

$$
P(Y)=\frac{1}{1+e^{-\left(b_{o}+b_{i} X_{1 i}\right)}}
$$

Where:

$P(Y)$ denotes the probability of an event $Y$ occuring;

$e \quad$ denotes the base of the natural logarithms

$b_{0} \quad$ denotes the constant

$X_{i} \quad$ denotes the predictor variable

$b_{1} \quad$ denotes the co-efficient or weight attached to the predictor

Where the outcome variable (i.e. mode choice) has more than two categories, the logistic equation is expressed in a multinomial or polychotomous form to include the additional predictors $X_{2}$ and $X_{n i}$ and their associated coefficients $b_{2}$ and $b_{n}$ as depicted in equation 2.

$$
P(Y)=\frac{1}{1+e^{-\left(b_{o}+b_{i} X_{1 i}+b_{2} X_{2 i}+\cdots+b_{n} X_{n i}\right)}}
$$

The results of the logistic regression analyses are interpreted based on odds ratio estimates of the models. Odds ratio $>1$ indicates that as the explanatory variable increases, the odds of the outcome of interest occurring also increases. Conversely, odds ratio $<1$ indicates that as the predictor variable increases, the odds of the outcome of interest occurring decreases (Field, 2013). 


\section{Results}

\subsection{Background socio-demographic characteristics of households}

A descriptive summary of the socio-demographic attributes of households and the employment characteristics of workers is presented in Table 1 . In terms of residential locations, $20 \%$ of the households represented in the data live in neighbourhoods within the historical-core of the study area. The remaining $44 \%$ and $36 \%$ live in inner-suburban and outer-suburban neighbourhoods, respectively. Average family size among the sampled households is four persons, compared to the metropolitan average of five persons. On the average, two adult individuals work in a household (SD = 0.737). Out of the 1,158 individual workers interviewed, $30 \%$ have their work located in the home or within the immediate vicinity of the home (i.e. home-based employment). The remaining $70 \%$ have non-home-based employment. The majority of individual workers (i.e. 88) have employment in the service sector. Occupations in this sector include small- to mediumscale work in trading and retail as well as formal sector jobs in administration, education, health, banking and finance.

The households of individual workers are classified into six income-groups. Total family income is taken as the sum of reported monthly earnings of all workers within the household. Given that pre-existing data on income-categories to which the data on income from the survey could be conformed does not exist in Ghana, households represented in the survey are classified into the six groups based on the percentile distributions of their reported incomes. Using this approach and taking the basic monthly income of $\mathrm{GHC}_{109^{3}}$ (US\$28) as the baseline, about $1 \%$ of the households, earning the first percentile income, are classified as urban poor. Households classified as low-income (25\%) earn between the $2^{\text {nd }}$ (GHC150) and $25^{\text {th }}$ (GHC700) percentile income. The respective percentile ranges for household classified as being lower-middle-income (27\%), upper-middle-income (23\%), high-income (20\%) and rich (4\%) are also presented in Table 1. Depending on the purpose of the analysis, the six income-groupings are aggregated into three groups namely, low-income (26\%), middle-income (50\%) and high-income $(24 \%)^{4}$

Table 1: Summary of socio-demographic characteristics of households

\begin{tabular}{|c|c|c|}
\hline & Household size & Mean $=4(S D=1.789)$ \\
\hline \multirow[t]{5}{*}{ Household characteristics } & Single-households & $16 \%$ \\
\hline & Couple (Married) & $65 \%$ \\
\hline & Couple (Co-habitation) & $4 \%$ \\
\hline & Single (Divorced \& Widowed) & $15 \%$ \\
\hline & Working members (aged 15 and above) & Mean $=2(S D=0.737)$ \\
\hline
\end{tabular}




\begin{tabular}{|c|c|c|}
\hline $\begin{array}{l}\text { Educational attainments } \\
\text { of adult individuals/ heads }\end{array}$ & $\begin{array}{l}\text { Basic School } \\
\text { Secondary \& Post-Secondary } \\
\text { Tertiary }\end{array}$ & $\begin{array}{l}41 \% \\
30 \% \\
29 \%\end{array}$ \\
\hline $\begin{array}{l}\text { Household income } \\
\text { (Monthly) and Income- } \\
\text { groupings }\end{array}$ & $\begin{array}{l}\text { Average monthly income } \\
\text { Urban poor }(1 \%)-1^{\text {st }} \text { Percentile } \\
\text { Low }(25 \%)-2^{\text {nd }}-25^{\text {th }} \text { Percentile } \\
\text { Lower-middle }(27 \%)-26^{\text {th }}-50^{\text {th }} \text { Percentile } \\
\text { Upper-middle }(23 \%)-53^{\text {rd }}-75^{\text {th }} \text { Percentile } \\
\text { High }(20 \%)-76^{\text {th }}-95^{\text {th }} \text { Percentile } \\
\text { Rich }(4 \%)-96^{\text {th }}-100^{\text {th }} \text { Percentile }\end{array}$ & $\begin{array}{l}\text { GHC1,200.00 (US\$312) } \\
\text { below GHC109.5 (US\$28.5) } \\
\text { GHC150-700 (US\$39-182) } \\
\text { GHC750-1200 (US\$195-312) } \\
\text { GHC1250-2000 (US\$325-520 } \\
\text { GHC2050-4000 (US\$533-1040) } \\
\text { GHC4100-14000 (US\$1066-3640) }\end{array}$ \\
\hline Urban Zone of residence & $\begin{array}{l}\text { Historical-core } \\
\text { Inner-suburb } \\
\text { Outer-suburb }\end{array}$ & $\begin{array}{l}20 \% \\
44 \% \\
36 \%\end{array}$ \\
\hline Housing types occupied & $\begin{array}{l}\text { Compound } \\
\text { Detached } \\
\text { Semi-detached } \\
\text { Flat }\end{array}$ & $\begin{array}{l}49 \% \\
22 \% \\
15 \% \\
14 \%\end{array}$ \\
\hline Housing tenancy types & $\begin{array}{l}\text { Owner-occupied } \\
\text { Renting } \\
\text { Rent-free }\end{array}$ & $\begin{array}{l}16 \% \\
50 \% \\
34 \%\end{array}$ \\
\hline $\begin{array}{l}\text { Job location of workers ( } \mathrm{n} \\
=1,158 \text { ) }\end{array}$ & Home-based work: None-home-based Work & $30 \%: 70 \%$ \\
\hline $\begin{array}{l}\text { Work industry of workers } \\
(n=1,158)\end{array}$ & $\begin{array}{l}\text { Agriculture } \\
\text { Manufacturing } \\
\text { Service (mainly commerce) } \\
\text { Service (Industry) } \\
\text { Other services }\end{array}$ & $\begin{array}{l}1 \% \\
1 \% \\
88 \% \\
8 \% \\
1 \%\end{array}$ \\
\hline
\end{tabular}

4.2 Analysis of metropolitan land use structure, individuals' employment locations and work trip production and distribution patterns

This section presents an analysis of the prevailing spatial structure of the case study metropolis. From a morphological perspective, the analyses presented here enable characterisation of the structure of the urban system by revealing the spatial configuration of major activity nodes within the metropolis. A detailed, TAZ-level analysis of the land use structure of the metropolis is also presented. The land use analysis at the TAZ level is important for two main reasons. Firstly, while the existing TAZs in the study area were designated around 2004, comprehensive and accurate data on land use patterns did not exist then. In the absence of land use data, the approach used was rather intuitive, relying mainly on an observation of broad distribution of activities and population within the metropolis to designate the $\mathrm{TAZs}^{5}$. Thus, the analysis presented here is the

\footnotetext{
${ }^{5}$ See the Urban Transport Planning and Management Studies for Kumasi report, 2004. Report made available for this research on request from the Department of Urban Roads, Kumasi.
} 
first to provide quantities of different land use types for each TAZ, using the newly available comprehensive land use datasets. Secondly, the results of the land use analysis are intended to set the context for examining and understanding patterns of spatial interactions between the home and the work-place that are anchored in the TAZs. In the end, the analyses of land use configuration and commute flows provide new insights into the both the morphological and functional dimensions of the metropolitan spatial structure.

\subsubsection{Characterising the spatial structure: activity nodes, TAZ system and land use configuration}

At the metropolitan scale, a morphological structure that resembles a polycentric configuration can be observed. As illustrated in Fig 2, five major clusters of urban functions are distinguishable These are the centrally located Central Business District (CBD) which is the main commercial and administrative node; three industrial clusters (i.e. Asokwa-Ahensan Industrial Enclave, Magazine Auto-mechanic Enclave and the Sokaban Wood Village) and a major educational enclave which hosts one of the largest public universities in Ghana (i.e. KNUST) and other educational establishments. A conceptual illustration of this polycentric morphology is further illustrated in Fig 3. This representation is intended to give a sense of scale to the prevailing spatial organization of the major activity nodes outlined above, by mapping the average road network distance from each activity node to the CBD, as well as the distance from each node to the other. Approximate distance between any two nodes is calculated in GIS as the actual road network distance linking their centroids. Taken together, the prevailing spatial structure reflects the distribution of major administrative, commerce and service functions within the urban system, which in turn, set the urban structural conditions that shape patterns of spatial interaction.

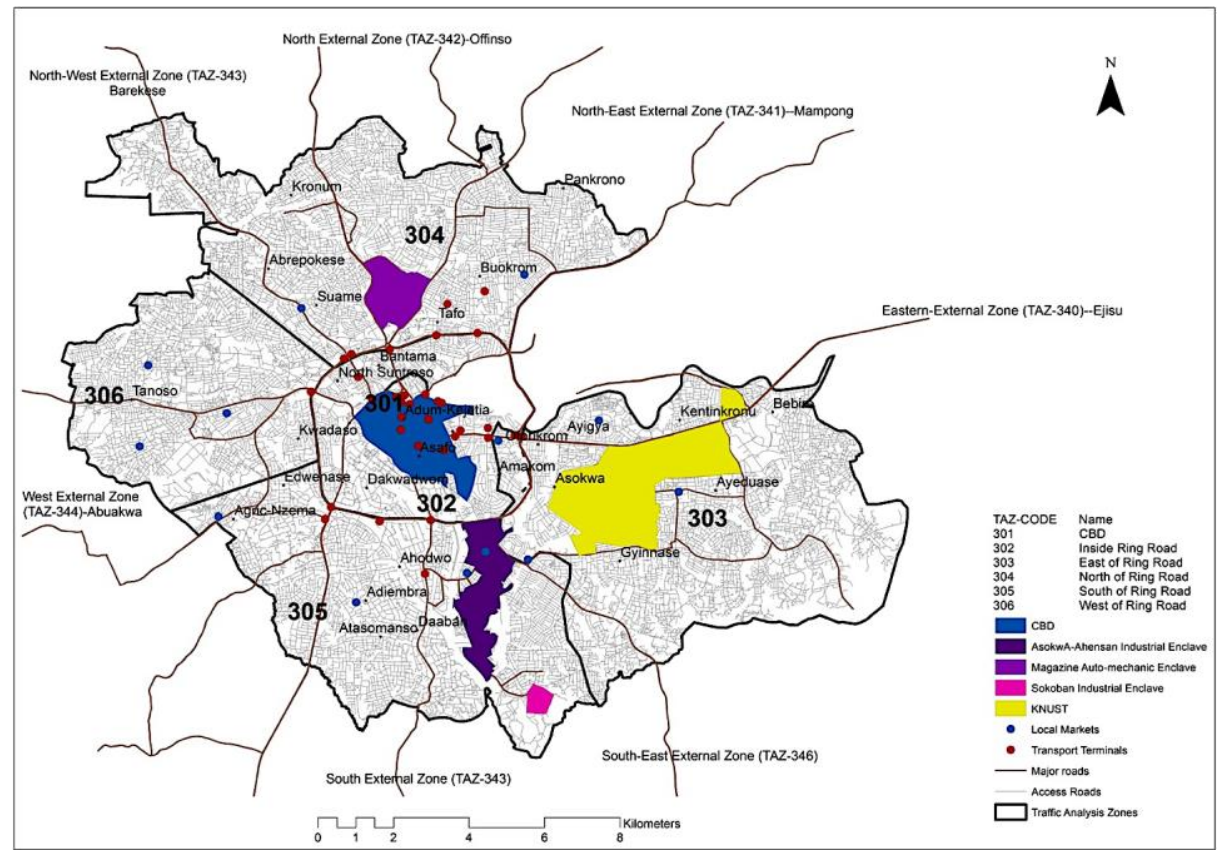

Fig 2: Six Macro/Aggregate Traffic Analysis Zone System in the Kumasi Metropolis 


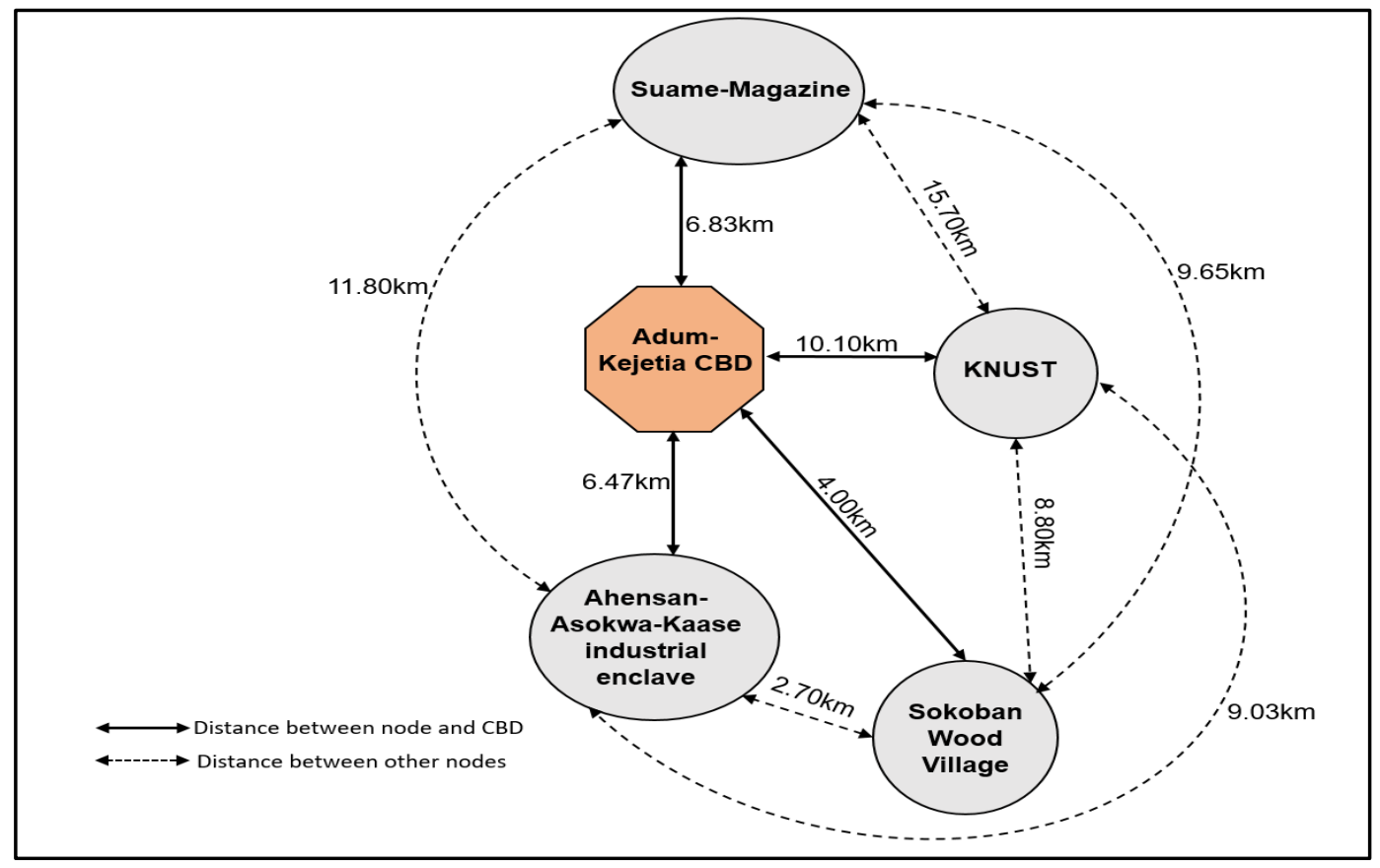

Fig 3: Conceptual illustration of the distribution of major activity nodes with actual road network distances between them

For the purpose of trip production and attraction analysis, the Kumasi Metropolis has been divided into 29 internal micro TAZs and seven external TAZs. The internal micro-TAZs are further aggregated into six macro-zones. As illustrated in Fig 2, the TAZ system closely follows the polycentric morphological structure, with each TAZ having at least one of the major activity nodes identified previously in addition its residential population. The land use structure within each of the TAZs, comprising the distribution of eight different land use types is mapped in Fig 5 . The quantities of the land use types within each TAZ and a TAZ's share of each of the eight land use types are also presented in Table 2 and Fig 4, respectively. The overall patterns that emerges from this analysis is that TAZs which have the highest concentration of a land use type within them tend to also have the highest share of the total of that land use type in the metropolis. For example, within TAZ-301 and TAZ -302, the dominant land uses are commercial and civic and culture $^{6}$. An estimated $44 \%$ and $13 \%$ of land uses in these TAZs are commercial (see Table 2) while about $62 \%$ of all commercial land uses in the metropolis are within these two TAZs alone (see Fig 4). From the observed patterns of land use distribution, three categories of TAZs are identified as follows:

- Centrally located TAZs of dominantly commercial and service functions. This comprises TAZ-301 and TAZ-302, which cover areas within the metropolitan CBD and the internal ring-road system of the metropolis;

\footnotetext{
${ }^{6}$ In the land use zoning code, civic and culture refers to land use by institutions such as various public sector departments and agencies.
} 
- TAZs of major residential and industrial functions. This consists of TAZ-304 and TAZ-305 which are located outside the ring-road system to the north and south, respectively. Within these TAZs are located the three major industrial enclaves in the metropolis and their supporting residential areas in the metropolis; and

- Dominantly residential suburban TAZs. These are TAZ -303 and TAZ-306. TAZ-303, consists of medium density residential areas located east of the ring road system. TAZ306 comprises medium to low density residential neighbourhoods in suburban locations to the west of the ring-road system.

Table 2: Distribution of land use types by Traffic Analysis Zones

\begin{tabular}{|c|c|c|c|c|c|c|c|c|c|c|c|c|}
\hline \multirow[b]{2}{*}{$\begin{array}{l}\text { Land use } \\
\text { Types }\end{array}$} & \multicolumn{6}{|c|}{ Land use (Hectares) } & \multicolumn{6}{|c|}{ Land use \% } \\
\hline & $\begin{array}{l}\text { TAZ } \\
301- \\
\text { CBD }\end{array}$ & $\begin{array}{l}\text { TAZ 302- } \\
\text { Inside } \\
\text { Ring } \\
\text { Road }\end{array}$ & $\begin{array}{l}\text { TAZ 303- } \\
\text { East of } \\
\text { Ring Road }\end{array}$ & $\begin{array}{l}\text { TAZ 304- } \\
\text { North of } \\
\text { Ring } \\
\text { Road }\end{array}$ & $\begin{array}{l}\text { TAZ 305- } \\
\text { South of } \\
\text { Ring Road }\end{array}$ & $\begin{array}{c}\text { TAZ 306- } \\
\text { West of } \\
\text { Ring } \\
\text { Road }\end{array}$ & $\begin{array}{l}\text { TAZ } \\
301- \\
\text { CBD }\end{array}$ & $\begin{array}{l}\text { TAZ 302- } \\
\text { Inside } \\
\text { Ring } \\
\text { Road }\end{array}$ & $\begin{array}{c}\text { TAZ 303- } \\
\text { East of } \\
\text { Ring } \\
\text { Road }\end{array}$ & $\begin{array}{l}\text { TAZ 304- } \\
\text { North of } \\
\text { Ring } \\
\text { Road }\end{array}$ & $\begin{array}{c}\text { TAZ } \\
\text { 305- } \\
\text { South } \\
\text { of Ring } \\
\text { Road }\end{array}$ & $\begin{array}{c}\text { TAZ 306- } \\
\text { West of } \\
\text { Ring } \\
\text { Road }\end{array}$ \\
\hline Residential & 20.580 & 636.038 & 2339.911 & 2612.505 & 2170.139 & 1359.528 & 8.520 & 34.658 & 29.465 & 50.217 & 38.571 & 35.795 \\
\hline Commercial & 106.227 & 238.203 & 32.013 & 83.131 & 65.463 & 25.922 & 43.979 & 12.980 & 0.403 & 1.598 & 1.164 & 0.682 \\
\hline $\begin{array}{l}\text { Civic and } \\
\text { Culture }\end{array}$ & 74.902 & 261.127 & 85.122 & 89.711 & 62.597 & 275.276 & 31.010 & 14.229 & 1.072 & 1.724 & 1.113 & 7.248 \\
\hline Industrial & 0.542 & 62.839 & 142.115 & 221.675 & 943.574 & 456.976 & 0.224 & 3.424 & 1.790 & 4.261 & 16.770 & 12.032 \\
\hline Mixed 7 & 1.777 & 120.494 & 149.064 & 396.823 & 132.692 & 120.792 & 0.736 & 6.566 & 1.877 & 7.628 & 2.358 & 3.180 \\
\hline Education & 2.743 & 226.506 & 2495.911 & 441.416 & 233.096 & 584.750 & 1.136 & 12.343 & 31.430 & 8.485 & 4.143 & 15.396 \\
\hline Transport & 8.765 & 22.965 & 0.250 & 105.129 & 1.003 & 0.00 & 3.629 & 1.251 & 0.003 & 2.021 & 0.018 & 0.000 \\
\hline Undeveloped & 26.007 & 266.989 & 2696.837 & 1252.053 & 2017.854 & 974.882 & 10.767 & 14.549 & 33.960 & 24.067 & 35.864 & 25.667 \\
\hline Total & 241.54 & 1835.16 & 7941.22 & 5202.44 & 5626.42 & 3798.13 & 100.00 & 100.00 & 100.00 & 100.00 & 100.00 & 100.00 \\
\hline
\end{tabular}

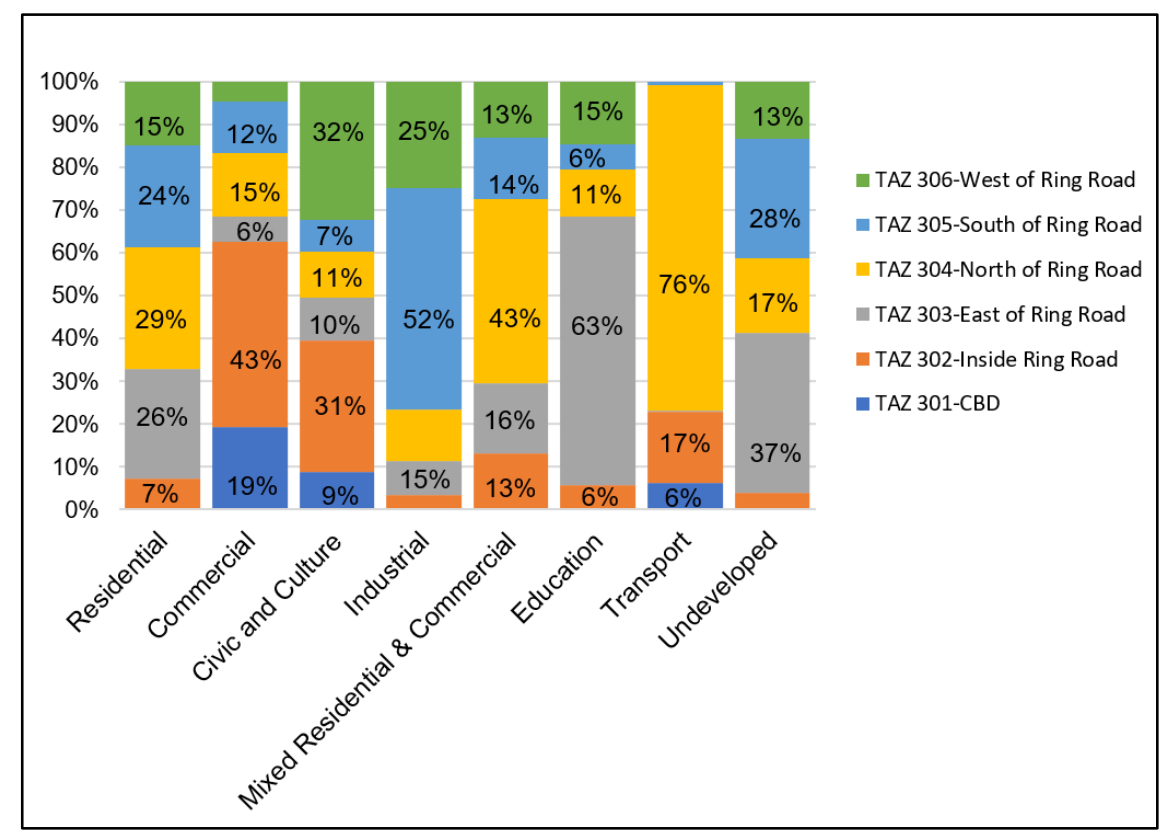

Fig 4: TAZs share of land use types in the KMA

\footnotetext{
${ }^{7}$ Refers to Residential and Commercial land use
} 


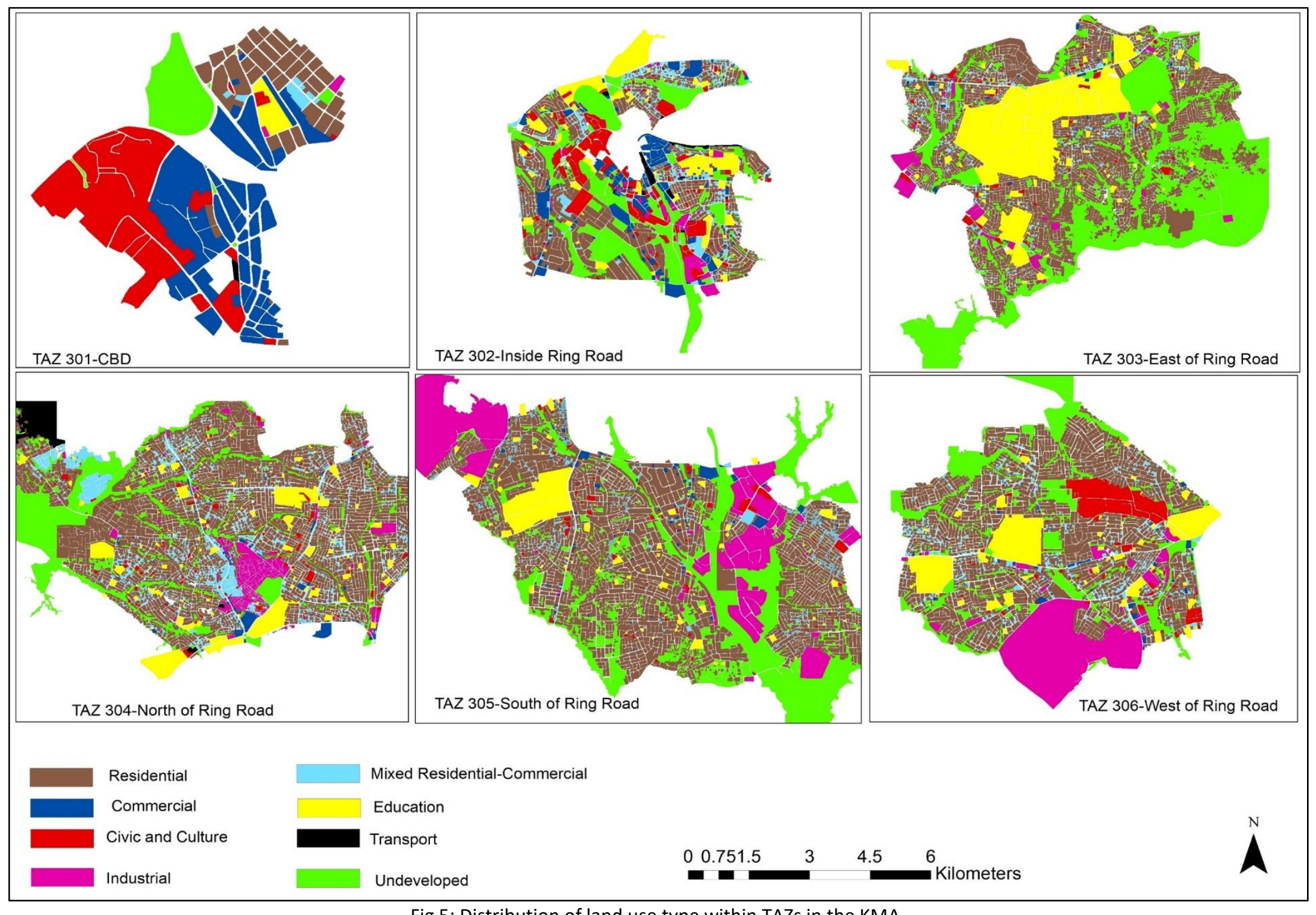

Fig 5: Distribution of land use type within TAZs in the KMA. 


\subsubsection{Employment locations and work trip origins and destinations}

With the analysis of TAZ-level land use distribution presented in the previous section, this section examines the home-work trip production and attraction patterns that are generated within the existing spatial structure. The locality of origin and destination of individuals' work journeys obtained through the survey are individually matched to their corresponding TAZs. The TAZ in which an individual's home is set as the origin while the TAZ in which the work-place is located is set as the destination of the trip. A summary of the home-work trip patterns is presented as an O-D matrix in Table 3. The results show that 93\% of all work journeys generated in the metropolis, are distributed internally among the six TAZs. The remaining seven percent of work trips generated within the metropolis have destinations outside it, in one of the external TAZs.

Table 3: TAZ-level origins and destinations of trips associated with home-based and non-home-based work

\begin{tabular}{|c|c|c|c|c|c|c|c|c|c|c|c|c|c|c|}
\hline \multirow[b]{3}{*}{ Origin TAZs } & \multicolumn{13}{|c|}{ Destination TAZs } & \multirow[b]{3}{*}{$\begin{array}{l}\text { Total } \\
\text { trip } \\
\text { Origins }\end{array}$} \\
\hline & \multicolumn{6}{|c|}{ Internal TAZs } & \multicolumn{7}{|c|}{ External TAZs } & \\
\hline & $\begin{array}{l}\text { TAZ } \\
301- \\
\text { CBD }\end{array}$ & $\begin{array}{r}\text { TAZ 302- } \\
\text { Inside } \\
\text { Ring Road }\end{array}$ & $\begin{array}{r}\text { TAZ 303- } \\
\text { East of } \\
\text { Ring } \\
\text { Road }\end{array}$ & $\begin{array}{r}\text { TAZ } \\
304- \\
\text { North } \\
\text { of Ring } \\
\text { Road } \\
\end{array}$ & $\begin{array}{r}\text { TAZ 305- } \\
\text { South of } \\
\text { Ring Road }\end{array}$ & $\begin{array}{r}\text { TAZ 306- } \\
\text { West of } \\
\text { Ring } \\
\text { Road }\end{array}$ & $\begin{array}{r}\text { TAZ } \\
340- \\
\text { Eastern }\end{array}$ & $\begin{array}{c}\text { TAZ } \\
341- \\
\text { North- } \\
\text { Eastern }\end{array}$ & $\begin{array}{r}\text { TAZ } \\
342- \\
\text { North }\end{array}$ & $\begin{array}{r}\text { TAZ } \\
343- \\
\text { North- } \\
\text { West }\end{array}$ & $\begin{array}{r}\text { TAZ } \\
344- \\
\text { West }\end{array}$ & $\begin{array}{r}\text { TAZ } \\
345- \\
\text { South }\end{array}$ & $\begin{array}{r}\text { TAZ 346- } \\
\text { South-East }\end{array}$ & \\
\hline TAZ 301-CBD & 14 & 2 & 2 & 1 & 1 & 0 & 0 & 0 & 0 & 0 & 0 & 0 & 1 & 21 \\
\hline TAZ 302-Inside Ring Road & 95 & 196 & 23 & 18 & 17 & 5 & 6 & 2 & 0 & 0 & 0 & 2 & 0 & 364 \\
\hline TAZ 303-East of Ring Road & 52 & 34 & 137 & 4 & 17 & 4 & 6 & 5 & 2 & 0 & 8 & 6 & 0 & 275 \\
\hline TAZ 304-North of Ring Road & 54 & 13 & 10 & 87 & 12 & 0 & 16 & 0 & 0 & 0 & 0 & 4 & 0 & 196 \\
\hline TAZ 305-South of Ring Road & 63 & 26 & 9 & 4 & 82 & 2 & 5 & 0 & 0 & 0 & 0 & 2 & 1 & 194 \\
\hline TAZ 306-West of Ring Road & 22 & 11 & 9 & 1 & 4 & 50 & 0 & 0 & 2 & 0 & 5 & 4 & 0 & 108 \\
\hline $\begin{array}{l}\text { Total trip } \\
\text { Destinations }\end{array}$ & 300 & 282 & 190 & 115 & 133 & 61 & 33 & 7 & 4 & 0 & 13 & 18 & 2 & 1158 \\
\hline
\end{tabular}

Summaries of the contributions, in percentage terms, of each of the TAZs to total work trip origins and total work trip destinations are presented in Fig 6. The results of work trip exchange quantities among the TAZs reflect the underlying land use patterns. For example, whereas about one-third of all work trips originate from the centrally located TAZs of dominantly commercial and service functions (i.e. TAZ-301 and TAZ-302), about half of all work trips generated in the metropolis terminate in these zones. The dual functions of other zones, as reflected in the concentration of residential and industrial and residential and educational activities, reflected in the patterns of work trip production and distribution patterns. For example, TAZ-303, being one of the dominantly residential zones, accounts for nearly a quarter of total work trip origins in the metropolis. This zone attracts $16 \%$ of total work trips, as a direct result of being the location of a major university. Thus, the number of home-origin trips generated by this zone is about 1.4 times lower than it attracts from other locations within the metropolis. Similarly, TAZ-304 and TAZ-305 given their dual industrial and residential functions, each contributes to $17 \%$ of work trip origins and $10 \%$ and $12 \%$ of trip destinations respectively. Being a major residential zone, TAZ- 
305 generates about 1.4 times more work trips than it attracts. TAZ-306 being a dominantly residential zone generates nearly twice more work trips than it receives.

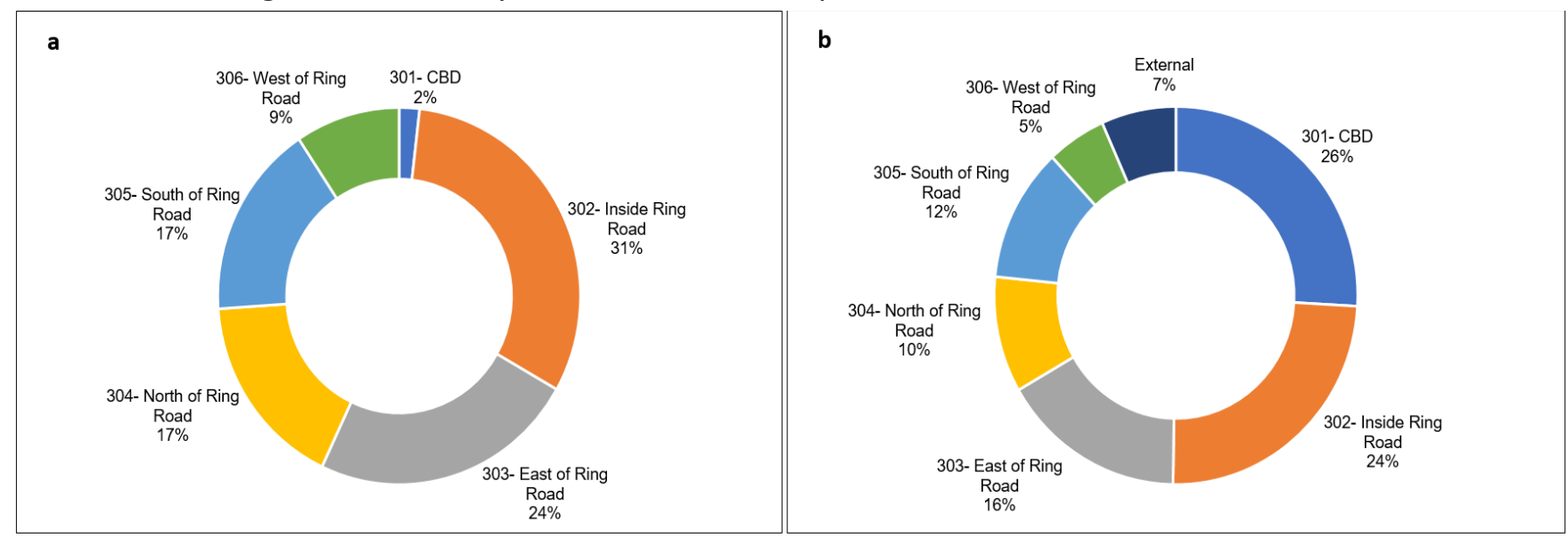

Fig 6: Contribution of TAZs to: (a) total work trip-origins and (b) total work trip-destinations

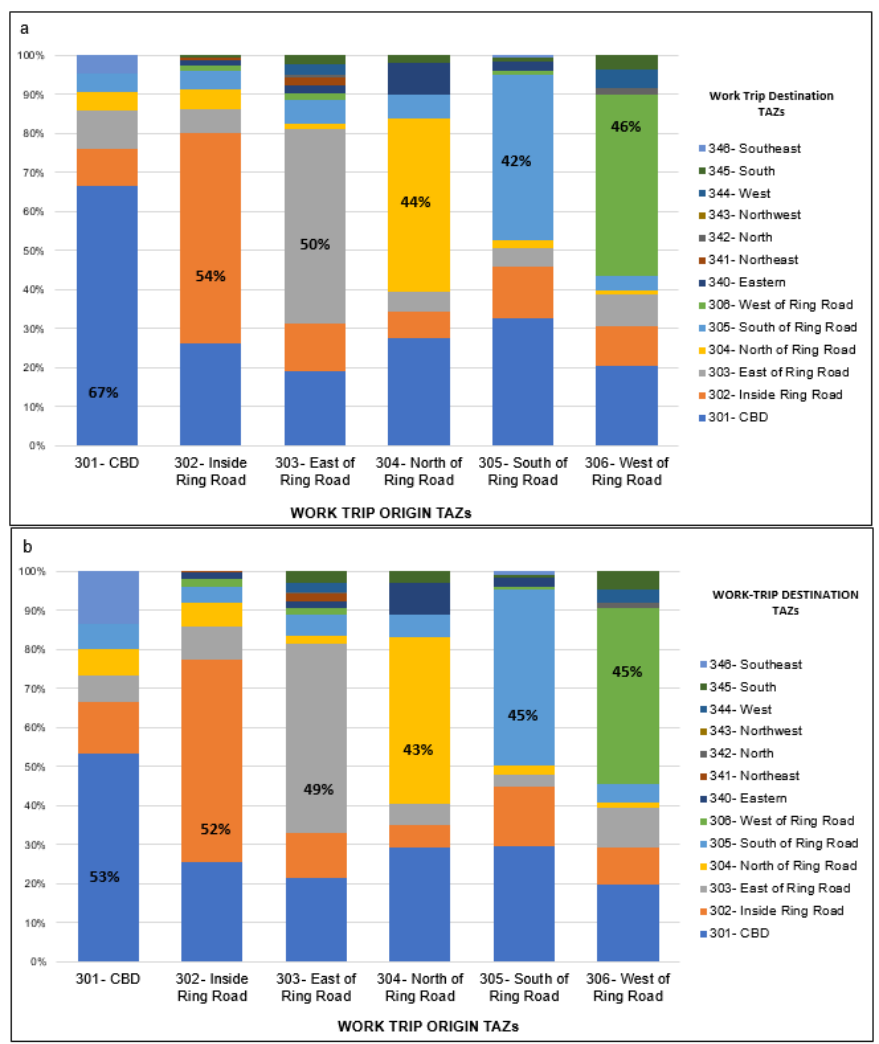

Fig 7: Distribution of total work trips of each origin TAZ among the destination TAZs for (a) home-based and non-home-based work-trips combined (b) non-home-based work trips only.

Taking each of the origin TAZs, the analysis further examines how the total trips generated by each TAZ are distributed among all the 12-TAZs (i.e. internal and external TAZs), including itself. The result is presented for work trips for all types of work (i.e. home-based work and non-homebased work, Fig 7a) and for non-home-based work only (Fig 7b). The results show that a considerable proportion of all work trips have the same origin and destination TAZ. This means 
that, most work trips that originate from a residential location within any of the TAZs end up in a job location within the same TAZ. For example, about $67 \%$ and $54 \%$ of all work trips starting from the two most central TAZs - TAZ301 and TAZ-302 respectively, have their destinations in these same TAZs. That about $30 \%$ of all workers have their jobs located either in their homes or within the immediate vicinity of the home at distances not exceeding $100 \mathrm{~m}(0.1 \mathrm{~km})$ could partly explain this. Even so, when the analysis is performed using data on non-home-work journeys only, a similar pattern emerges as shown in Fig $\mathbf{7 b}$.

\subsection{Work travel mode choice}

This section presents the results of the data on transport modes individuals use to complete the work journeys presented in the previous section. The frequency of use of the different transport mode options, derived from the five-day work travel mode use data obtained from the respondents, is presented for work trips starting from the home (Fig 8a) and the return legs of the trip (Fig 8b). The 5-day work travel mode choice data has been grouped under three classes of use frequency namely, 'always' - where a particular mode is used every day of work in the 5day period; 'frequent'-where a particular mode is used three to four times every week to work; and 'infrequent' - where mode is used once to twice every week to work.

Results of the five-day work travel mode choice show that, overall mode choice for both the home-origin and return leg of work journeys are consistent among the respondents across the different modes. Among private car users who drive alone to work, about $90 \%$ of work trips starting from the home and $88 \%$ of return trips involve driving alone for the five-day period. Among public transport (mini-bus/trotro) users, about $80 \%$ of return work journey are undertaken every day of the week by this mode. In $56 \%$ and $48 \%$ of the cases, commuters using buses and taxis to work, respectively use their respective modes throughout the week. This category of commuters, the data shows, substitute between public transport in mini-bus/trotro and taxi or buses on some days. Finally, most workers (93\%) who walk to work also do so consistently for all five-working days in the week. From this data, individuals using any particular mode between three and five times in a week are assigned that particular mode as their main work travel mode choice. The results show that whereas $21 \%$ of workers commute in private cars either driving alone (17\%) or sharing a ride with other members of their household $(4 \%), 45 \%$ of commuters use public transport. One-third of workers chose walking as their main work travel mode (Table 4). 


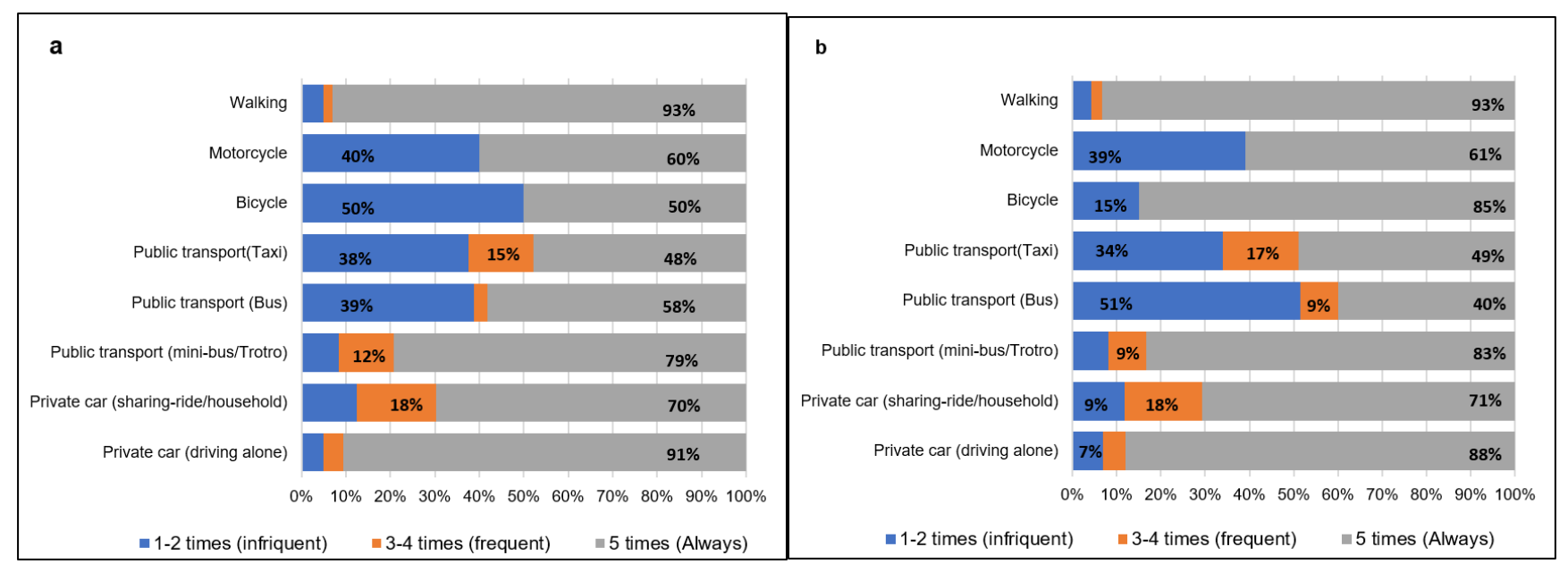

Fig 8: Frequency of travel mode use (a) from home to work (b) from work to home for a five-day period.

Table 4: Work travel mode choice in the Kumasi Metropolis derived from a five-day mode use data

\begin{tabular}{lcc}
\hline Travel Mode & $\begin{array}{c}\text { Number of } \\
\text { commuters }\end{array}$ & Percentage \\
\hline Private Car (driving alone) & 171 & 17 \\
Private Car (sharing a ride with other household members) & 49 & 4 \\
Public Transport (mini-bus/trotro) & 417 & 36 \\
Public Transport (bus) & 24 & 2 \\
Public Transport (taxi) & 84 & 7 \\
Bicycle & 4 & 0.3 \\
Motorcycle & 6 & 0.5 \\
Walking & 403 & 33 \\
\hline Total & $\mathbf{1 1 5 8}$ & $\mathbf{1 0 0}$ \\
\hline
\end{tabular}

In addition to revealed work travel mode choices presented above, the underlying decision utility considerations, which reflect individuals' expectations of the benefits of using the different travel mode alternatives, are examined. Fig 9 provides a summary of individual workers' evaluation of the level of importance they attach to a set of five factors in their travel mode choice decisionmaking, namely; affordability, comfort, privacy, flexibility and travel time. 


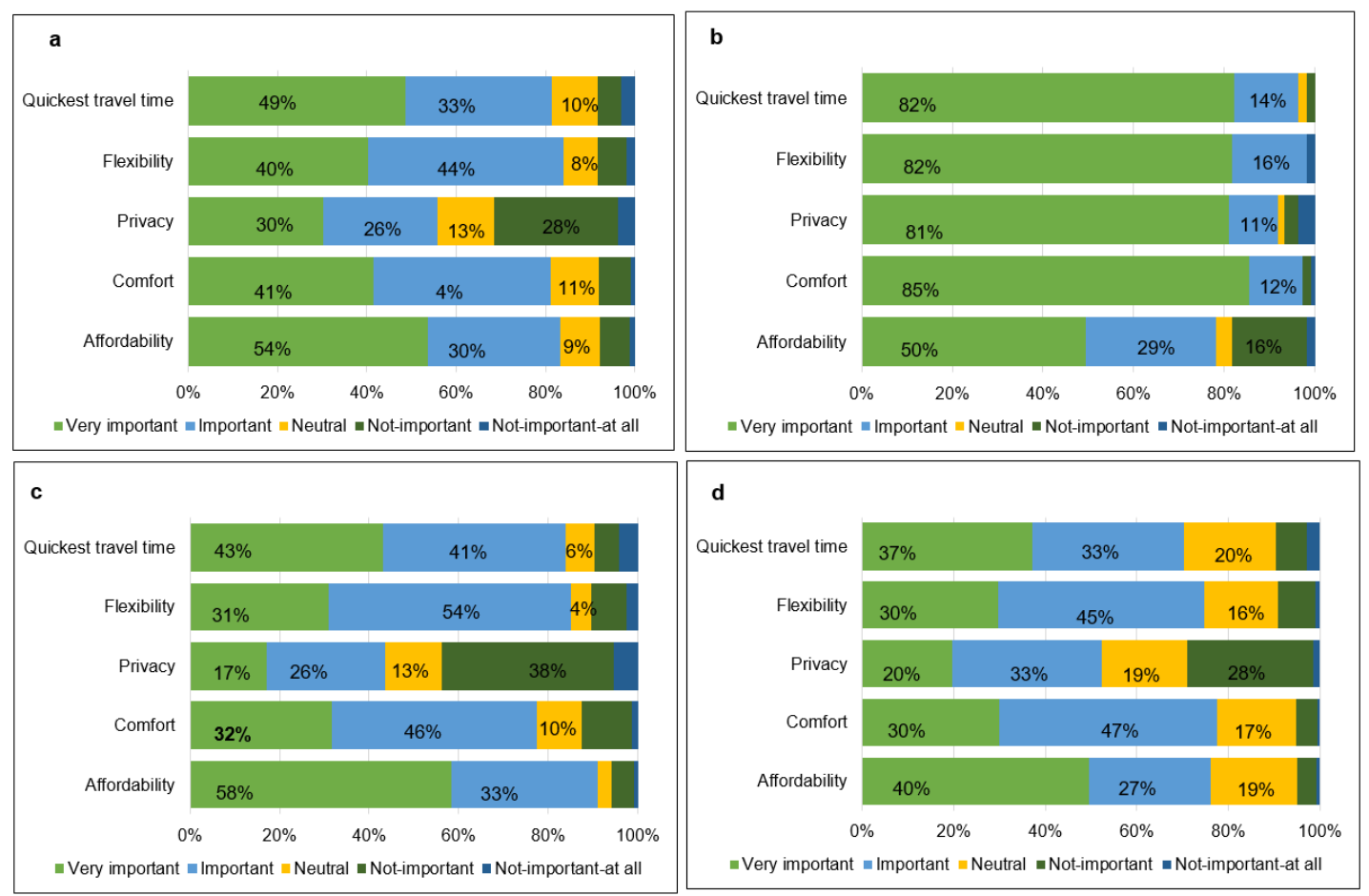

Fig 9: Summary of responses to travel mode choice decision utility factors by (a) all commuters (b) private car users (c) public transport users and $(\mathrm{d})$ individuals who walk to work

As shown in Fig 9b the need for travel comfort, privacy, flexibility, and quick travel times are ranked very highly among private car users, with over $80 \%$ of them indicating these as especially important reasons for their mode choice. Less than half (49\%) of private car users associate their choice with the importance they attach to affordability. Among public transport users, 58\% indicate affordability as an important reason for commuting to work using this mode (see Fig 9c). Comfort, privacy and flexibility on the other hand, are considered as being of relatively less importance in mode choice among public transport users. Indeed, responses to a separate question included in the survey, revealed that nearly a quarter of public transport users are of the view that their travel mode does not offer comfortable commuting. The majority (84\%) are also of the view that the general conditions of public transport in the metropolis and service quality are rather poor.

\subsubsection{Understanding the determinants of car ownership and use as work travel mode: A binary logistic regression analysis}

Car-ownership is one of the most significant determinants of car-use as work travel mode. In view of this, the analysis of work travel mode choice first explores the factors that explain auto ownership at the household level. Initial assessment of Omnibus Test of Model Co-efficient and model fitting information demonstrated a good fit between the data and the regression model. Table 5 shows the results of a binary logistic regression model of households' car-ownership and its use as work travel mode. 
Table 5: Determinants of private-car ownership and choice as work travel mode ${ }^{8}$

\begin{tabular}{|c|c|c|c|c|}
\hline \multirow[b]{2}{*}{ Predictors } & \multicolumn{4}{|c|}{ 95\% C.I. for EXP(B) } \\
\hline & $b(S E)$ & Lower & Odds Ratio & Upper \\
\hline Low-income & $0^{\mathrm{b}}$ & & & \\
\hline Middle-income & $2.038(0.61) * *$ & 2.32 & 7.673 & 25.384 \\
\hline High Income & $3.368(0.618) * * *$ & 8.649 & 29.029 & 97.434 \\
\hline Education of household-head (tertiary =1) & $1.491(0.187) * * *$ & 3.08 & 4.441 & 6.404 \\
\hline Marital status (couple $=1$ ) & $-0.158(0.225)$ & 0.549 & 0.854 & 1.327 \\
\hline Family size & $0.181(0.054) * *$ & 1.079 & 1.199 & 1.332 \\
\hline Distance of home to CBD & $-0.110(0.048) *$ & 0.815 & 0.895 & 0.983 \\
\hline Historical-core residence & $0^{\mathrm{b}}$ & & & \\
\hline Inner-suburb residence & $0.7(0.303) *$ & 1.111 & 2.014 & 3.652 \\
\hline Outer suburb residence & $1.245(0.369) * *$ & 1.686 & 3.473 & 7.155 \\
\hline Affordability (important = 1) & $-0.542(0.253) * *$ & 0.354 & 0.582 & 0.956 \\
\hline Comfort (important $=1$ ) & $0.265(0.426)$ & 0.565 & 1.304 & 3.007 \\
\hline Privacy (important = 1) & $1.568(0.255) * * *$ & 2.911 & 4.797 & 7.906 \\
\hline Flexibility (important = 1) & $-0.867(0.39) *$ & 0.196 & 0.42 & 0.904 \\
\hline Quickest travel time (important $=1$ ) & $1.385(0.426) * *$ & 1.735 & 3.996 & 9.203 \\
\hline Constant & $-5.677(0.743) * * *$ & & 0.003 & \\
\hline
\end{tabular}

Results of the analysis show that likelihood of car ownership and use increases with higher household income. High-income households (earning monthly income of GHC2,050 and above) have odds of owning and commuting to work in a private car, 29 times higher than low-income households. In the case of middle-income households (i.e. earning incomes between $\mathrm{GH} C 750$ and GHC2000), the odds are relatively smaller, although nearly eight times higher than low-income households. Moreover, having at least one adult member of the household being tertiaryeducated is associated with odds of owning and commuting to work in a private car, four times higher than those with low-levels of education, controlling for other factors. Households with relatively larger family size would own a private car and have their working members drive to work, controlling for income and education. As distance between the place of residence and the CBD and the place of residence and place of work decreases, the odds of a household owning a car and individual workers driving to work decreases ${ }^{9}$. In addition, worker's having residence in the inner- and outer-suburban locations of the metropolis have odds of commuting to work by a

\footnotetext{
${ }^{8}$ Categorical variables in the model are coded as follows: Education is a two-category variable coded as: 1-Tertiary, 0-basic \& secondary; Marital status is a two-category variable coded as: 1-couple, 0-Single; 'Affordability', 'Comfort', 'Privacy', 'Flexibility' and 'Quickest travel time' are each entered in the model as a two-category variables coded as 1-important, 0-not-important. 'Important' as a category comprises 'very important' and 'important' while 'not-important' comprises 'neutral', 'not-important' and 'not-important-at-all' categories presented in Fig 9.

9 The average distance from the place of residence to the CBD was $7 \mathrm{~km}(\mathrm{SD}=2.85)$ while that of the home to the place of work was $4.5 \mathrm{~km}$ ( $S D=2.99$ ). Home-work distances were objectively measured in google by using information on locality of each individual's home and work location. Using this approach, network distance along major arterials linking the home and work place were derived. Where more than one route was found, distances were averaged as a way of considering differences in travel distances which result depending on route choice.
} 
private car two and 3.5 times higher, respectively, than those residing in the historical-core neighbourhoods. Finally results of the analysis show that whereas greater importance to affordability as a decision utility factor reduces the likelihood of individuals driving to work, individuals who attach greater importance to privacy are nearly five times more likely to own and drive to work. Similarly, workers who attach greater importance to flexibility in travel have odds of choosing to commute to work in a private car four times higher than those who do not.

\subsubsection{Determinants of choice between walking and motorized forms of transport as work} travel mode: a binary logistic regression analysis

As walking constitutes the primary mode of transport to work for about one-third of the 1,158 individual workers interviewed, the factors that determine whether an individual worker would choose walking over motorized forms of transport ${ }^{10}$ are explored in this section (Table 6).

Table 6: Determinants of choice between walking and motorized transport as work travel modes

\begin{tabular}{|c|c|c|c|c|}
\hline & \multirow[b]{2}{*}{$b(S E)$} & \multicolumn{3}{|c|}{ 95\% C.I. for EXP(B) } \\
\hline & & Lower & $\begin{array}{l}\text { Odds } \\
\text { Ratio }\end{array}$ & Upper \\
\hline High-Income & $0^{\mathrm{b}}$ & & & \\
\hline Low-income & $1.691(0.342) * * *$ & 2.776 & 5.425 & 10.6 \\
\hline Middle-income & $1.299(0.294) * * *$ & 2.062 & 3.666 & 6.518 \\
\hline Education (tertiary $=1$ ) & $0.734(0.262) * *$ & 1.248 & 2.083 & 3.478 \\
\hline Non-car-ownership (Yes =1) & $1.529(0.334) * * *$ & 2.397 & 4.613 & 8.878 \\
\hline Job location (home-based =1 non-home-based $=0$ ) & $2.838(0.391) * * *$ & 7.936 & 17.089 & 36.801 \\
\hline Home-work distance $(\mathrm{km})$ & $-0.37(0.055) * * *$ & 0.621 & 0.691 & 0.769 \\
\hline Home-work distance * Job location (home-based) & $0.181(0.085) *$ & 1.014 & 1.198 & 1.415 \\
\hline Affordability (important $=1$ ) & $0.969(0.279) * *$ & 1.524 & 2.634 & 4.553 \\
\hline Quickest travel time (important $=1$ ) & $-0.385(0.3)$ & 0.378 & 0.68 & 1.226 \\
\hline Flexibility (important $=1$ ) & $0.165(0.284) *$ & 0.676 & 1.18 & 2.06 \\
\hline Constant & $-3.227(0.471) * * *$ & & 0.04 & 10.6 \\
\hline $\begin{array}{r}\text { Note: } \mathrm{R}^{2}=0.65 \text { (Nagelkerke), } \\
\text { bThis parameter is set to zero } b \\
\text { Model fitting inf } \\
\text { Hosmer and Lemeshow }\end{array}$ & $\begin{array}{l}\text { I) }{ }^{*} p<0.05, * * p<0 \\
\text { undant } / \text { set as the } r \\
2.727, d f=14, p<0.00 \\
\text { st: } X^{2}=10.396, d f=8\end{array}$ & $\begin{array}{l}01 * * * p<0 . C \\
\text { ference categ } \\
p=0.093\end{array}$ & & \\
\hline
\end{tabular}

The results show that workers from low-income households have odds of walking to work, five times higher than workers from high income households. Non-tertiary educated workers are twice more likely to choose walking over motorized transport as work travel mode. Controlling for other factors, workers belonging to non-car-owning households have odds of walking to work nearly five times higher than those with households owning a car. As expected, individuals whose work-places are located inside the home or within the immediate vicinity of the home (i.e. homebased workers) have odds of walking to work 17 times higher than non-home-based workers. In general, the analysis found that home-work distance separation exceeding $0.3 \mathrm{~km}$ would be covered using motorized mode of transport while walking is associated with relatively shorter

\footnotetext{
10 The analysis is based on data from 1,150 out of the 1,158 individuals interviewed; motorbike and cycling as work travel modes have been
} excluded from the analysis due to low data counts. 
distances. Finally, workers who attach greater importance to affordability in choosing their work travel mode, are nearly three times more likely to walk to work than choose a motorized form of transport, controlling for other factors. While the need for the quickest mode of travel reduces the odds of walking, workers who prioritize flexibility in their work travel mode choice are a little more likely to walk to work than opt for motorized transport (odds ratio $=1.18$ ).

\subsubsection{Work transport mode choice among non-private car users: a multinomial logistic regression analysis}

The final part of the analysis of determinants of work travel mode choice specifies a multinomial regression model to estimate the likelihood of choice among three alternatives, namely public transport (mini-bus/trotro), public transport (taxi) and walking. For this model, walking is first set as the reference category to examine the propensity of a worker choosing to commute to work in a mini-bus/trotro vs walking, taxi vs walking. By changing the reference category within the same model specification, it is possible to gain further insights from the analysis. In this analysis, the reference category was set as taxi to compare the likelihood of choice between this mode and the mini-bus/trotro. The data used for this analysis is based on the sample of 928 individuals out of the total 1,158 interviewed and therefore excludes private-car ownership and use, and bicycle and motorcycle use.

Results of the analysis are summarised in Table 7 and explained as follows. Between the minibus/trotro and walking, and taxi and walking, the results show that the odds of a worker using the former is 1.3 times and 1.5 times higher than using the latter, respectively, as home-work distance increases beyond a quarter of a kilometre. Overall, as income increases, households who do not have private cars tend to travel to work in one of two public transport modes - minibus/trotro or taxi (see Table 7 for odds ratios). Even so, between the two modes, high-income earners have higher preference for the taxi than the mini-bus/trotro. Indeed, likelihood estimates in a separate binary choice analysis specified between the mini-bus/trotro and taxi revealed that high-income earners have odds of commuting in a taxi 3.5 times higher than commuting in a minibus/trotro $(b=1.256$, Wald $=0.024 ; 95 \%$ C.I. for $\operatorname{EXP}(B)$ : lower-bound $=1.180$, upper- bound $=$ 10.45). Moreover, home-based job location was associated with odds of choosing to walk to work, 34 times higher than doing so in a mini-bus/trotro. Non-home-based workers are also three times more likely to choose the mini-bus/trotro over taxi as work travel mode, controlling for other factors. Workers who prioritize affordability are less likely to choose a taxi compared to a mini-bus/trotro while commuters who prioritize privacy but do not own a car are nearly seven times more likely to choose the former compared to the latter. 
Table 7: Determinants of choice between walking, and two public transport mode alternatives $(n=928)$

\begin{tabular}{|c|c|c|c|c|c|c|}
\hline & \multicolumn{2}{|c|}{$\begin{array}{c}\text { Public transport (mini-bus/trotro) } \\
\text { vs Walking }\end{array}$} & \multicolumn{2}{|c|}{ Public transport (taxi) vs Walking } & \multicolumn{2}{|c|}{ mini-bus/trotro vs taxi } \\
\hline & $b(S E)$ & $\begin{array}{l}\text { Odds Ratio } \\
(95 \% \mathrm{Cl})\end{array}$ & $b(S E)$ & $\begin{array}{l}\text { Odds Ratio } \\
(95 \% \mathrm{Cl})\end{array}$ & $b(S E)$ & $\begin{array}{l}\text { Odds Ratio } \\
(95 \% \mathrm{Cl})\end{array}$ \\
\hline Intercept & $-4.784(0.503) * * *$ & 1.339 & $-6.6(0.85) * * *$ & 1.345 & $0.415(0.703)$ & 0.995 \\
\hline Home-work distance (km) & $0.292(0.045) * * *$ & 4.782 & $0.297(0.056) * * *$ & 5.977 & $-0.005(0.044)$ & 0.800 \\
\hline High Income & $1.565(0.362) * * *$ & 1.473 & $1.788(0.541) * *$ & 2.732 & $-0.223(0.509)$ & 0.539 \\
\hline Middle-income & $0.388(0.253)$ & & $1.005(0.454) *$ & & $-0.617(0.452)$ & \\
\hline Low-income & $0^{b}$ & 34.308 & $0^{b}$ & 10.445 & $0^{\mathrm{b}}$ & 3.285 \\
\hline Home-based job location & $3.535(0.344) * * *$ & & $2.346(0.503) * * *$ & & $1.189(0.567) *$ & \\
\hline Non-Home-based job location & $0^{\mathrm{b}}$ & 7.345 & $0^{\mathrm{b}}$ & 0.743 & $0^{\mathrm{b}}$ & 0.101 \\
\hline Affordability (not-important) & $1.994(0.362) * * *$ & & $-0.297(0.412)$ & & $-2.291(0.433) * * *$ & \\
\hline Affordability (important) & $0^{\mathrm{b}}$ & 0.581 & $0^{\mathrm{b}}$ & 2.078 & $0^{\mathrm{b}}$ & 3.573 \\
\hline Comfort (not-important) & $-0.542(0.347)$ & & $0.731(0.666)$ & & $1.274(0.64) *$ & \\
\hline Comfort(important) & $0^{\mathrm{b}}$ & 0.347 & $0^{\mathrm{b}}$ & 2.388 & $0^{\mathrm{b}}$ & 6.874 \\
\hline Privacy (not-important) & $-1.057(0.236) * * *$ & & $0.871(0.397) *$ & & $1.928(0.371) * * *$ & \\
\hline Privacy (important) & $0^{\mathrm{b}}$ & 0.842 & $0^{\mathrm{b}}$ & 1.376 & $0^{\mathrm{b}}$ & 1.634 \\
\hline Quicker time travel (not-important) & $-0.172(0.313)$ & & $0.319(0.565)$ & & $0.491(0.544)$ & \\
\hline Quicker time travel (important) & $0^{\mathrm{b}}$ & & $0^{\mathrm{b}}$ & & $0^{\mathrm{b}}$ & \\
\hline
\end{tabular}

Note: $\mathrm{R}^{2}=0.60$ (Nagelkerke), 0.51 (Cox and Snell) *p<0.05, **p<0.01***p<0.001

${ }^{\mathrm{b}}$ This parameter is set to zero because it is redundant/set as the reference category 


\subsection{Work travel times and out-of-pocket travel costs}

This section presents results of the analysis of the last aspect of work travel, which is the travel time and costs associated with individuals' work commutes. Firstly, the start times home-towork trips in the mornings (Fig 10a) and that of return journeys in the evening (Fig 10b) are examined. The results show that a significant proportion of morning home-to-work (i.e. 80\%) occur between the early hours of 6:00am and 9:00am. Whereas, nearly half of all work journey start times within this period occur in the early morning off-peak period between 6:00am and 7:00am, 44\% of them occur during the early morning peak hours between 7 and $9 \mathrm{am}$. The remaining seven percent of morning work trips occur during the off-peak periods after 9am. In the case of return journeys (figure $5.9 \mathrm{~b}$ ), whereas about $23 \%$ of trips are taken during the offpeak hours before $4: 30 \mathrm{pm}$, about $40 \%$ of evening work-to-home trips occur during the peak hours between $4: 30 \mathrm{pm}$ and $6: 30 \mathrm{pm}$. The remaining $37 \%$ of journeys occur during the evening off-peak hours after 6:30pm. From the survey, it was found that most of the morning peak-hour commuters (54\%) and evening peak-hour commuters (74\%), did not choose their travel start times to avoid traffic congestion. Instead, the observed work journey times are consistent with formal rules regarding work reporting and closing hours, which act as a form authority constraint on when workers leave home to work and vice versa. This constraint, in turn, creates the peak period traffic congestion experienced by commuters as their work travel times converge and manifest as traffic flows on major arterials in the metropolis.

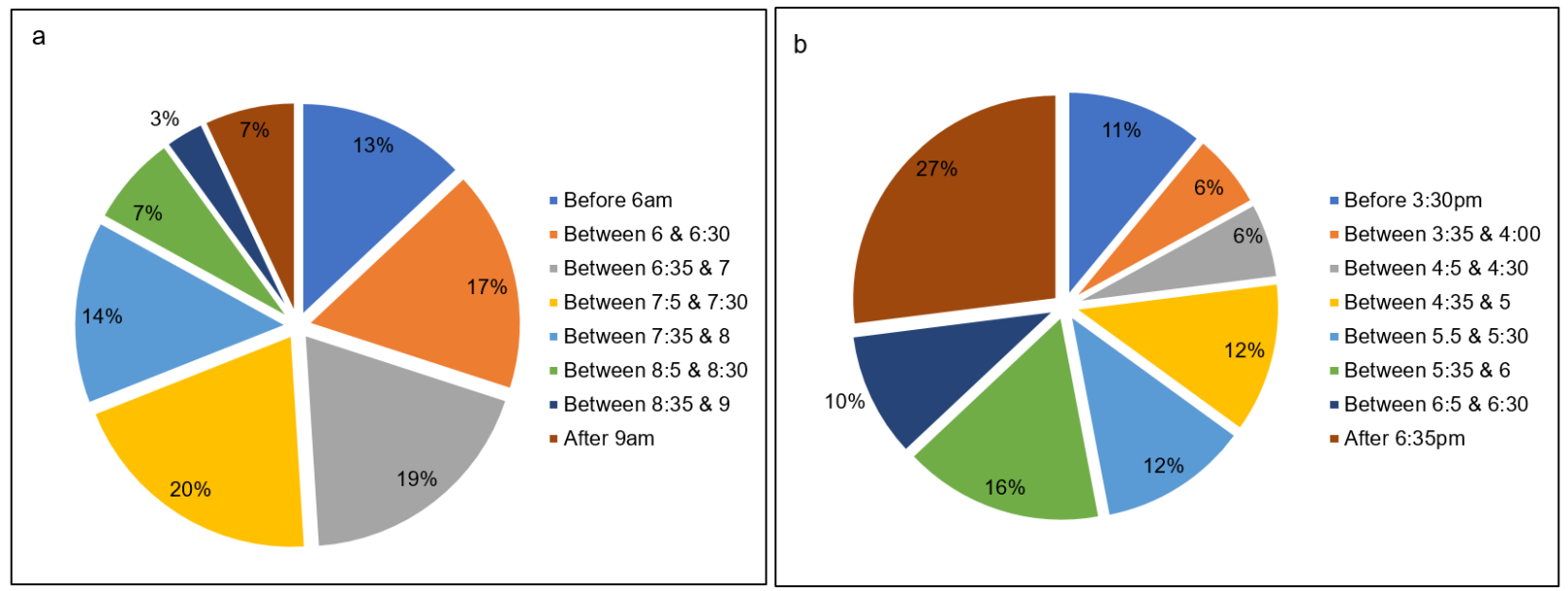

Figure 10: Start times for (a) Morning home-to-work trips and (b) Evening work-to-home trip

Summary descriptive statistics data on actual times spent traveling to and from work are presented in Table 8. The analysis shows morning and evening work travel times for all trips, trips associated with home-based work only and trips associated with non-home-based work only. On the average, commuters spend about 25 minutes and 33 minutes travelling from home-to-work in the mornings and returning to home from work in the evenings respectively. Variations in travel times, in addition to the above averages are presented in Table 8. Spearman's Rho 
correlation analysis shows a positive association between job location (i.e. whether home-based or non-home-based) and travel time $(r=0.581, p<0.001)$; mode of transport to work and travel time $(r=0.634, p<0.001)^{11}$ and TAZ origin and destination of work trips and travel time ${ }^{12}(r=$ $0.547, p<0.001)$. A positive association also exists between home-work distance and travel time $(r=0.597, p<0.001)$.

Table 8: Travel times for morning work trips

\begin{tabular}{|c|c|c|c|c|c|c|}
\hline \multirow[b]{2}{*}{$\begin{array}{l}\text { Travel time } \\
\text { (Minutes) }\end{array}$} & \multicolumn{2}{|c|}{ All single work trips (\%) } & \multicolumn{2}{|c|}{$\begin{array}{l}\text { Home-based work trips only } \\
\text { (\%) }\end{array}$} & \multicolumn{2}{|c|}{$\begin{array}{l}\text { Non-home-based work } \\
\text { trips only (\%) }\end{array}$} \\
\hline & $\begin{array}{l}\text { Home-work } \\
\text { (mornings) }\end{array}$ & $\begin{array}{l}\text { Work-home } \\
\text { (Evenings) }\end{array}$ & $\begin{array}{l}\text { Home-work } \\
\text { (mornings) }\end{array}$ & $\begin{array}{l}\text { Work-home } \\
\text { (Evenings) }\end{array}$ & $\begin{array}{l}\text { Home-work } \\
\text { (mornings) }\end{array}$ & $\begin{array}{l}\text { Work-home } \\
\text { (Evenings) }\end{array}$ \\
\hline $\begin{array}{l}\text { below } 10 \\
\text { minutes }\end{array}$ & 19 & 11 & 58 & 40 & 6 & 2 \\
\hline 10 to 19 & 21 & 5 & 27 & 14 & 18 & 2 \\
\hline 20 to 29 & 17 & 2 & 9 & 4 & 19 & 1.5 \\
\hline 30 to 39 & 18 & 67 & 2 & 36 & 24 & 77 \\
\hline 40 to 49 & 12 & 1 & 1 & 0 & 16 & 1 \\
\hline 50 to 59 & 4 & 1 & 2 & 0 & 5 & 1.5 \\
\hline $60+$ & 10 & 12 & 0 & 6 & 13 & 5 \\
\hline Average & 25.0 & 32.85 & 5.0 & 10 & 30.0 & 32.86 \\
\hline SD & 19.79 & 18.61 & 10.89 & 19.37 & 19.01 & 16.131 \\
\hline Maximum & 120 & 105 & 60 & 105 & 120 & 105 \\
\hline
\end{tabular}

Source: Based on Field Survey, February 2015

The monthly out-of-pocket costs, calculated as a percentage of total household income for private car users, using reported weekly spending on fuel and for public transport users using reported daily costs incurred as fares are presented in Table 9. This measure of transport cost, therefore, does not include non-fuel and no-fare costs such as vehicle maintenance costs. Expectedly, private car users spend more (i.e. GHc200) on the average as fuel costs compared to the average monthly transport fare cost of $\mathrm{GH} C 80$ for public transport users. Overall, the percentage of income spent on work travel increases with higher incomes. However, transport cost as a proportion of household income decreases as relatively lower income households, although there are variations as the breakdown of the result show. For example, whereas workers from low-income households who use private cars spend on the average GHC100 every month on transport, representing between $14 \%$ and $66 \%$ of their incomes, workers in households classified as rich spend on the average GHC300 every month on transport, representing between only two and seven percent of their monthly earnings.

A series of correlation analysis confirmed the above findings. A Spearman Rho correlation analysis shows a positive association between household income-group and out-of-pocket travel

\footnotetext{
${ }^{11}$ Transport mode is dichotomized into two categories; (i) non-motorized- (i.e. walking) and (ii) motorized-private car and all public transport modes

${ }^{12}$ TAZ origin and destination of trips is dichotomized into two categories; (i) whether TAZ origin and destination of a trip is the same; and (ii) whether TAZ origin and destination of a trip is different.
} 
cost $(r=0.548 p<0.001)$ and a negative association between work travel mode choice (i.e. private car vs public transport) and travel costs $(r=-0.538 p<0.001)$. Furthermore, Pearson correlation analysis shows a rather small but significant negative association between transport costs and number of working days $(r=-0.113 p=0.003)$; positive association between home-work distance and transport cost incurred $(r=0.123 \mathrm{P}<0.001)$ and a positive relationship between the number of adult workers in a household and total transport monthly spending ( $r=0.245, p<0.001)$.

Table 9: Total monthly out-of-pocket transport costs for different income groups and mode use

\begin{tabular}{|c|c|c|c|c|c|c|}
\hline \multirow{2}{*}{ Travel Mode } & \multirow[b]{2}{*}{ Income-group } & \multirow[b]{2}{*}{ Percentage } & \multirow{2}{*}{$\begin{array}{c}\text { Monthly Income } \\
\text { Range (GHC) }\end{array}$} & \multicolumn{2}{|c|}{ Monthly Transport Cost (GHC) } & \multirow{2}{*}{$\begin{array}{l}\text { Transport cost } \\
\text { as percentage of } \\
\text { income }\end{array}$} \\
\hline & & & & Median & SD & \\
\hline \multirow{5}{*}{$\begin{array}{l}\text { Private car } \\
\text { users }{ }^{13}\end{array}$} & Low & 1 & $150-700$ & 100 & 141.0 & $66-14.0$ \\
\hline & Lower-middle & 11 & $750-1200$ & 175 & 117.6 & $23-14.5$ \\
\hline & Upper-middle & 27 & $1250-2000$ & 120 & 138.0 & $9.6-6.0$ \\
\hline & High & 47 & $2050-4000$ & 275 & 265.8 & $13.4-6.9$ \\
\hline & Rich & 14 & $4100-14000$ & 300 & 338.0 & $7.3-2.1$ \\
\hline \multirow{5}{*}{$\begin{array}{l}\text { Public } \\
\text { transport } \\
\text { users }\end{array}$} & Low & 19 & $150-700$ & 50 & 59.1 & $33.3-7.2$ \\
\hline & Lower-middle & 33 & $750-1200$ & 63 & 40.2 & $8.4-5.2$ \\
\hline & Upper-middle & 27 & $1250-2000$ & 100 & 72.6 & $8.0-5.0$ \\
\hline & High & 19 & $2050-4000$ & 139 & 94.0 & $6.8-3.5$ \\
\hline & Rich & 2 & $4100-14000$ & 250 & 146.5 & $6.1-1.8$ \\
\hline
\end{tabular}

\section{Discussion}

This study has examined the relationships among urban spatial structure, mobility patterns and the associated short-term travel decisions at the individual-level in the Kumasi Metropolis in Ghana, West Africa. Analysis of the spatial structure at the intra-urban scale has been undertaken by exploring the spatial organization of major activity nodes within the metropolis. The results reveal a polycentric morphology, comprising five major adjacent activity nodes within the urban system. The analysis further shows that the six macro-TAZ system, delineated purposely for commuting flow analysis in the metropolis, reflect strongly the prevailing multi-centre structure, and integrates their surrounding residential populations. Using newly available land use datasets, this research has, for the first time, provided precise quantities of eight different land use types to further characterise the structure of the urban system at the TAZ-level. Three broad TAZs of activity locations are identified from the land use analysis, namely; centrally located TAZs of dominantly commercial and service functions; TAZs of major residential and industrial functions in the inner and outer suburban areas; and dominantly residential suburban TAZs.

Within the prevailing spatial structure described above, the study examined the emergent homework trip production and attraction patterns. A key finding from this analysis is that, nearly all work trips generated in the metropolis (i.e. 93\%) have destinations located within the metropolis.

\footnotetext{
${ }^{13}$ The analysis is based on fuel costs only and does not include other costs such as car maintenance and insurance premiums.
} 
This suggests that a considerable proportion of the resident working population do not travel outside the administrative boundaries of the Kumasi Metropolis for work. Thus, from an intraurban perspective, work commutes in the study area tend to originate from inner-suburban and outer-suburban residential areas and disperse towards the major activity nodes located within the metropolis. Also, from an inter-urban perspective of commute flows, this finding appears to contradict the phenomenon of reverse commuting that has been observed in other metropolitan areas across Europe and North America in particular, whereby round work trips are increasingly being taken from an urban area to the surrounding sub-urban and peri-urban areas (see e.g. Hincks and Wong, 2010; Aguilera et al., 2009; Cervero, 2004).

Although the TAZ-level analysis of work trip and destinations show that that all the five adjacent activity nodes in the urban system attract work trips, the magnitude of the flow is not equal. The results show that about half of all work trips have their destination in the centrally located TAZs of dominantly commercial and service functions, which also mark the CBD of the metropolis. On the contrary, these central zones serve as the home-origins of only one-third of work trips, reinforcing the initial argument that commuting flows are mainly directed from the suburban, dominantly residential areas to the CBD and other the other adjacent activity nodes. These findings suggest that the metropolis exhibits the features of a hierarchical polycentric urban system, with a dominant CBD. Indeed, this underscore both the morphological and functional dimensions of urban spatial structure that has been documented in previous studies from different urban and urban-region contexts (see Fernández-Maldonado et al., 2013; Vasanen, 2012; Garcia-Lo'pez and Mun iz, 2010; Hall and Pain, 2006). For example, as FernándezMaldonado et al., (2013) found in their analysis of spatial structure in Latin American Metropolitan areas, the structure of these urban systems is polycentric, with the existence of a single dominant centre giving it a hierarchical configuration. Thus, the findings of the current study offer useful empirical insights for conceptualizing and theorising about intra-urban urban spatial structure in the case study metropolis, which could be described as not being monocentric, but rather as being morphologically and functionally polycentric with a relatively stronger centre (i.e. $\mathrm{CBD}$ ).

Another important finding from the trip production and attraction patterns observed in the metropolis is that nearly half of work trips start and end within the same TAZ. This finding reveals two important insights about the forces underlying observed land use configuration and patterns of spatial interaction in the metropolis. The first insight is that the structure of the metropolitan economy and employment do manifest both in the land use structure and commuting patterns. This assertion is best understood within the wider context of the large share of small-scale commercial activities, often classified in the literature as belonging to the informal economy. As previous research has shown, urban informal economy workers in Ghana tend to work from 
home or within the immediate vicinity of the home (see e.g. Gough et al., 2013; Gough, 2010; Boapeah, 2001; Acheampong, 2018). Indeed, the data on work locations of individuals represented in this study show that nearly one-third of them, the majority of whom are involved in work in the informal economy, have home-based employment locations. In land use terms, home-based economic activities account for the distribution of mixed-residential-andcommercial land uses observed through the analysis of the metropolitan land use structure. In commuting terms, this phenomenon suggests that the distance separation between the home and work-place for a sizeable proportion of workers is relatively shorter, hence the observed pattern whereby most work journeys begin and end in the same TAZ.

The second insight derived from the analysis of the work trip production and distribution patterns is that, even when home-based work is excluded from the analysis, a considerable proportion of work journeys still begin and end in the same TAZ. Given that each of the macro-TAZs takes one of the major activity nodes as its focal point of economic activities and employment, this last finding in particular, further supports the observed polycentric structure of urban system, which ensures that overall, individual workers having their residence in the metropolis commute relatively shorter: from the analysis, average work distance is about $4.5 \mathrm{kms}$. While the spatial separation between activities in any urban area could partly be a function of its physical size, this finding appears to be consistent with the findings of previous studies that show that with the alternative centres it offers to the $\mathrm{CBD}$, a polycentric spatial structure generally tends to reduce commuting distance (see e.g. Muñiz and Garcia-López, 2019; Grunfelder et al., 2015; Asikhia and Nkeki, 2013; Zhao et al., 2011; Næss, 2007).

Moreover, this study has systematically examined the determinants of individuals' work travel mode choices, by specifying a series of logistic regression models. The results show that residence in suburban neighbourhoods, non-home-based employment locations, objectively measured distances between individuals' home locations and employment locations and household income influence motorized transport use for work purposes. The likelihood of car-ownership and use as work travel mode increases among workers in households with relatively higher incomes living in a suburban neighbourhood. In addition, travel decision utility factors which reflect expectations of privacy, comfort and travel speed/time also have considerable influence on car use for work journeys. A recent study by Agyemang (2017) found that comfort as an expected utility benefit did not appear to influence car use among respondents in Accra, the capital. However, consistent with the findings of the current study, the aforementioned study found that overall, there are perceived advantages of the car over other modes, which makes it the preferred choice for some groups of commuters. 
Furthermore, among individuals in non-car-owning households, living in an inner-suburban or outer-suburban neighbourhood was found to be associated with a higher propensity for using motorized transport mode in the form of public transport (i.e. minibus/trotro) or taxi, as opposed to walking to work. On the contrary, comparing choice between non-motorized (walking) and motorized forms of transport for work commute, the analysis show that lower-income levels, residence in the historical-core neighbourhoods of the metropolis and having home-based employment location, all influence choice of the former. Consistent with the findings of this study, previous research has shown that inner-city locations with higher housing or employment densities are associated with lower levels of auto ownership (Pinjari et al, 2011) and relatively shorter non-motorized commuting (Gim, 2013; Yang and Ferreira, 2008). Furthermore, based on empirical evidence from Hangzhou Metropolitan Area in China, Næss (2013), found that suburban residents where twice more likely to use motorized mode of transport (i.e. private car and taxi) than their inner-city counterparts. Similarly, Aditjandra et al., (2013) in their study of commuting characteristics in North East England residential neighbourhoods, also found that residents of inner-city traditional neighbourhoods perceived greater opportunities for public transport use and walking than residents of suburban neighbourhoods.

The final aspect of the analysis of mobility characteristics focused on work travel times and the costs associated with the choice of different travel modes. The results show that work journey start times in the morning and evening times are determined primarily by authority constraints in the form of formal rules regarding work reporting and closing hours, although among some commuters, this constraint, in addition to the objective to avoid traffic congestion, influence their work journey start times. Furthermore, the study found strong associations between reported times spent traveling to work and travel mode choice, objectively measured home-work distance separation, employment location types (i.e. home-based or non-home-based) and whether a given work journey starts and ends in the same TAZ. In terms of commuting costs, the analyses show that household spending on transport is strongly correlated with whether multiple workers are present, car ownership, whether non-car users commute to work using public transport (taxi or mini-bus/trotro) and the income-group of the household of the individual worker.

\section{Policy implications of findings}

The detailed empirical insights presented in this study have a number of policy implications. As the results show, suburbanization is one of the key drivers of car-ownership and use. Autodependence, in turn, increases overall levels of motorization, congestion and pollution which can lead to poor public health in urban areas. At the same time, the poor condition of existing public transport services in the metropolis implies that people are more likely to own cars if they can afford to do so. Forced car ownership, especially among low-income households can have 
negative impacts on their living standards. Indeed, as the analysis of out-of-pocket travel costs in this paper shows, low-income households owning cars tend to spend a significantly higher percentage of their income on fuel costs alone. Thus, within wider considerations of equitable and sustainable urban development, it would be crucial for policy to prioritise and invest in efficient and affordable public transit that meets the mobility needs of diverse groups of people in the metropolis.

Perhaps, a positive finding that emerged from this study is the fact that a considerable number of individuals walk the entire way from home to work. This is an immense potential that urban planning and policy can tap into and support, as globally, walking is seen as one of the sustainable modes of transport. Creating pedestrian-friendly and walkable environments at the neighbourhood and metropolitan scales would certainly support individuals who are currently walking to work, and potentially encourage more people to walk for relatively shorter work trips. Moreover, the analysis show that even for motorized intra-urban trips, distances covered by commuters tend to be relatively shorter (i.e. $4.5 \mathrm{~km}$ on the average). As such distances could be undertaken by non-motorized forms of transport such as bicycling, urban development planning could prioritize investment in the infrastructure for this form of mobility, with the aim to promoting sustainable mobility choices in the long term.

Finally, the analysis of commute flows has shown that the existing urban structure of the Kumasi Metropolis is clearly providing alternative activity sub-centres to the CBD. However, the prevailing multi-centre spatial structure is very much hierarchical, with the CBD remaining quite dominant in terms of total trip attraction. In the long term, urban planning and policy could bring about further decentralization by developing the existing activity sub-centres and establishing new sub-centres of employment, especially in the outer-suburban areas. This approach could form part of a wider portfolio of strategic interventions for achieving a more diffused pattern of commute flows, and for ultimately reducing commuting times, congestion and travel-related energy consumption and pollution.

\section{Conclusions and future work}

This study has explored the links among urban spatial structure, travel patterns and mode choice in the Kumasi Metropolis, the second largest metropolitan area in Ghana. By undertaking detailed analyses of the spatial organization of activity nodes, land use patterns, commuting flows and mode choice, the study has helped to characterise the prevailing structure of the urban system and how this, in turn, shapes home-work trip production and attraction patterns. Based on these analyses, a number of policy implications have been drawn, which could be pursued to bring about sustainable urban transportation and spatial development outcomes. The current study uses the administrative boundary of the Kumasi metropolis to analyse intra-urban spatial 
structure and mobility patterns. Future work could adopt a functional-region approach by expanding the geographical scale to encompass the Kumasi metropolis and the surrounding periurban districts. Adopting this functional-region approach would allow to examine functional interdependencies and characterise the spatial structure-commuting nexus at the inter-urban scale. Most importantly, comparative studies in other developing countries, especially rapidly urbanizing metropolitan areas in Sub-Saharan Africa, would improve our understanding of the links between spatial structure and travel behaviour for purposes of theory building and practical policy applications.

\section{Appendix 1}

Table 10: Distribution of sample frame and sample size of households

\begin{tabular}{|c|c|c|c|c|}
\hline A. Sample & distribution & n level & & \\
\hline Sub-metro name & Households & Percentage & Allocated sample & Percentage \\
\hline Asokwa & 36183 & 8 & 60 & 8 \\
\hline Bantama & 63722 & 15 & 96 & 15 \\
\hline Kwadaso & 60233 & 14 & 93 & 14 \\
\hline Manhyia & 41886 & 10 & 64 & 10 \\
\hline Nhyiaeso & 34624 & 8 & 54 & 8 \\
\hline Oforikrom & 73343 & 17 & 110 & 17 \\
\hline Subin & 48105 & 11 & 73 & 11 \\
\hline Suame & 23318 & 5 & 35 & 5 \\
\hline Tafo & 55277 & 13 & 80 & 13 \\
\hline Total & 436691 & 100 & 665 & 100 \\
\hline
\end{tabular}

B. Sample size distribution at settlement level within each sub-metropolitan unit

\begin{tabular}{|c|c|c|c|c|}
\hline Sub-metro name & Proxy settlement & Households in proxy settlement & Allocated sample & Percentage \\
\hline \multirow[t]{4}{*}{ Asokwa } & Asokwa & 6240 & 19 & 32 \\
\hline & Atonsu & 17102 & 34 & 57 \\
\hline & Gyenyaasi & 3517 & 7 & 12 \\
\hline & Total & 26859 & 60 & 100 \\
\hline \multirow[t]{4}{*}{ Bantama } & Bantama & 9716 & 51 & 53 \\
\hline & North Suntreso & 5146 & 27 & 28 \\
\hline & Abrepo kese3 & 3440 & 18 & 19 \\
\hline & Total & 18302 & 96 & 100 \\
\hline \multirow[t]{5}{*}{ Kwadaso } & Kwadaaso & 10173 & 36 & 39 \\
\hline & Edwenase & 5291 & 19 & 20 \\
\hline & Tanoso & 7375 & 25 & 27 \\
\hline & Agric-Nzema & 3032 & 13 & 14 \\
\hline & Total & 25871 & 93 & 100 \\
\hline \multirow[t]{5}{*}{ Manhyia } & Ashtown & 11004 & 25 & 39 \\
\hline & Buokrom & 11749 & 26 & 41 \\
\hline & Dichemso/Yen & 5857 & 13 & 20 \\
\hline & Yawoso & & & \\
\hline & Total & 28610 & 64 & 100 \\
\hline \multirow[t]{6}{*}{ Nhyieso } & Ahodwo & 2157 & 7 & 13 \\
\hline & Adiembra & 5076 & 18 & 33 \\
\hline & Atasomanso & 3891 & 14 & 26 \\
\hline & Daaban & 3514 & 12 & 22 \\
\hline & Dakwadwom & 612 & 3 & 6 \\
\hline & Total & 15250 & 54 & 100 \\
\hline \multirow[t]{2}{*}{ Oforikrom } & Anloga/Oforikrom & 9549 & 27 & 25 \\
\hline & Ayigya & 14355 & 40 & 36 \\
\hline
\end{tabular}




\begin{tabular}{|c|c|c|c|c|}
\hline & Oforikrom & 8069 & 23 & 21 \\
\hline & Ayeduase & 4340 & 12 & 11 \\
\hline & Bebre & 274 & 1 & 1 \\
\hline & Kentinkrono & 2365 & 7 & 6 \\
\hline & Total & 38952 & 110 & 100 \\
\hline \multirow[t]{3}{*}{ Suame } & suame & 1880 & 8 & 23 \\
\hline & Kronom & 6131 & 27 & 77 \\
\hline & Total & 8011 & 35 & 100 \\
\hline \multirow[t]{5}{*}{ Subin } & Asafo & 8162 & 18 & 25 \\
\hline & Amakom & 16353 & 35 & 48 \\
\hline & Adum/kejetia & 3946 & 8 & 11 \\
\hline & Fante Newtown & 5500 & 12 & 16 \\
\hline & Total & 33961 & 73 & 100 \\
\hline \multirow[t]{4}{*}{ Tafo } & Old Tafo & 22062 & 60 & 75 \\
\hline & pankrono & 7969 & 20 & 25 \\
\hline & Total & 30031 & 80 & 100 \\
\hline & GRAND TOTALS & 225847 & 665 & \\
\hline
\end{tabular}

\section{References}

Abane, A. M. (2011). Travel behaviour in Ghana: empirical observations from four metropolitan areas. Journal of Transport Geography, 19(2), 313-322.

Acheampong R.A. (2019a) Chapter 11: Integrated Spatial Development and Transportation Planning. In: Spatial Planning in Ghana-Origins, Contemporary Reforms and Practices, and New Perspectives $1^{\text {st }}$ ed. P. 231-267. The Urban Book Series. Springer, Cham https://doi.org/10.1007/978-3-030-02011-8 11

Acheampong R.A. (2019b) Chapter 9: Urbanization and Settlement Growth Management. In: Spatial Planning in Ghana-Origins, Contemporary Reforms and Practices, and New Perspectives $1^{\text {st }}$ ed. P. 171-203. The Urban Book Series. Springer, Cham https://doi.org/10.1007/978-3-030-02011-8 9

Acheampong, R.A \& Siiba, A. (2019) Modelling the determinants of car-sharing adoption intentions among young adults: the role of attitude, perceived benefits, travel expectations and socio-demographic factors. Transportation DOI: 10.1007/s11116-019-10029-3

Acheampong, R. A. (2018). Towards incorporating location choice into integrated land use and transport planning and policy: A multi-scale analysis of residential and job location choice behaviour. Land use policy, 78, 397-409.

Acheampong, R. A., \& Silva, E. A. (2015). Land use-transport interaction modeling: A review of the literature and future research directions. Journal of Transport and Land use, 8(3), 11-38.

Adarkwa, K.K. and Poku-Boansi, M., (2011). Rising vehicle ownership, roadway challenges and traffic congestion in Kumasi. In Adarkwa, K.K. (ed) Future of the tree: Towards growth and development of Kumasi, pp.128-152. University Printing Press, KNUST, Kumasi 
Aditjandra, P. T., Mulley, C., \& Nelson, J. D. (2013). The influence of neighbourhood design on travel behaviour: Empirical evidence from North East England. Transport Policy, 26, 54-65.

Agyemang, E. (2017). Mode choice for long distance trips: Evidence from the Greater Accra Metropolitan Area of Ghana. Journal of Transport Geography, 64, 150-157.

Aguilera, A., Wenglenski, S., \& Proulhac, L. (2009). Employment suburbanisation, reverse commuting and travel behaviour by residents of the central city in the Paris metropolitan area. Transportation Research Part A: Policy and Practice, 43(7), 685-691.

Alonso, W. (1964). Location and land use. Toward a general theory of land rent. Cambridge, Massachusetts: Harvard University Press.

Amoh-Gyimah, R., \& Aidoo, E. N. (2013). Mode of transport to work by government employees in the Kumasi metropolis, Ghana. Journal of Transport Geography, 31, 35-43.

Angel, S., Blei, A. M., Civco, D. L., \& Parent, J. (2012). Atlas of urban expansion. Cambridge, MA: Lincoln Institute of Land Policy.

Armah, F. A., Yawson, D. O., \& Pappoe, A. A. (2010). A systems dynamics approach to explore traffic congestion and air pollution link in the city of Accra, Ghana. Sustainability, 2(1), 252-265.

Asikhia, M. O., \& Nkeki, N. F. (2013). Polycentric employment growth and the commuting behaviour in Benin Metropolitan Region, Nigeria. Journal of Geography and Geology, 5(2), 1.

Bates, J. (2000). History of demand modeling. Handbook of Transport Modeling 1: 11-33.

Batty, M. (2013). The new science of cities, Cambridge, MA, and London: MIT Press.

Birago, D., Mensah, S. O., \& Sharma, S. (2017). Level of service delivery of public transport and mode choice in Accra, Ghana. Transportation research part F: traffic psychology and behaviour, 46, 284-300.

Boapeah S. (2001). The informal economy in Kumasi. In: Adarkwa KK (ed) The fate of the tree: planning and managing in the development of Kumasi, Ghana, Woeli Publishing Services, Accra, pp 59-77

Bowman, J. L., \& Ben-Akiva, M. E. (2001). Activity-based disaggregate travel demand model system with activity schedules. Transportation research part a: policy and practice, 35(1), 1-28.

Cervero, R. (2013). Linking urban transport and land use in developing countries. Journal of Transport and Land Use, 6(1), 7-24. 
Cervero, R., \& Murakami, J. (2010). Effects of built environments on vehicle miles traveled: evidence from 370 US urbanized areas. Environment and planning A, 42(2), 400-418.

Cervero, R. (2004). Job isolation in the US: narrowing the gap through job access and reversecommute programs. Running on empty: Transport, social exclusion and environmental justice, 181-196.

Choi, K. (2018). The influence of the built environment on household vehicle travel by the urban typology in Calgary, Canada. Cities, 75, 101-110.

Davoudi, S. (2003) Polycentricity in European spatial planning: from an analytical tool to a normative agenda, European Planning Studies, 11, pp. 979-999.

De Vos, J., Mokhtarian, P. L., Schwanen, T., Van Acker, V., \& Witlox, F. (2016). Travel mode choice and travel satisfaction: bridging the gap between decision utility and experienced utility. Transportation, 43(5), 771-796.

Ding, C., Liu, C., Zhang, Y., Yang, J., \& Wang, Y. (2017a). Investigating the impacts of built environment on vehicle miles traveled and energy consumption: Differences between commuting and non-commuting trips. Cities, 68, 25-36.

Ding, C., Wang, D., Liu, C., Zhang, Y., \& Yang, J. (2017b). Exploring the influence of built environment on travel mode choice considering the mediating effects of car ownership and travel distance. Transportation Research Part A: Policy and Practice, 100, 65-80.

Dissanayake, D., \& Morikawa, T. (2002). Household travel behavior in developing countries: Nested logit model of vehicle ownership, mode choice, and trip chaining. Transportation Research Record: Journal of the Transportation Research Board, (1805), 45-52.

Esson, J., Gough, K. V., Simon, D., Amankwaa, E. F., Ninot, O., \& Yankson, P. W. (2016). Livelihoods in motion: Linking transport, mobility and income-generating activities. Journal of Transport Geography, 55, 182-188.

Ewing, R., \& Cervero, R. (2010). Travel and the Built Environment. Journal of the American Planning Association, 76(3), 265-294

Fernández-Maldonado, A. M., Romein, A., Verkoren, O., \& Parente Paula Pessoa, R. (2014). Polycentric structures in Latin American metropolitan areas: Identifying employment subcentres. Regional Studies, 48(12), 1954-1971.

Field, A. (2013). Discovering statistics using IBM SPSS statistics. sage.

Frank, L., Bradley, M., Kavage, S., Chapman, J., \& Lawton, T. K. (2008). Urban form, travel time, and cost relationships with tour complexity and mode choice. Transportation, 35(1), 37-54. 
Garcia-Lo' pez, M.-A. and Mun iz, I. (2010) Employment decentralisation: polycentricity or scatteration? The case of Barcelona, Urban Studies, 47, pp. 3035-3056.

Ghana Statistical Service (2013). 2010 Population and Housing Census. National Analytical Report. Url: http://www.statsghana.gov.gh/docfiles/2010phc/National Analytical Report.pdf [accessed: April 20, 2017]

Ghana Statistical Service, (2014), Ghana Living Standards Survey, Round 6, 2014 http://www.statsghana.gov.gh/docfiles/glss6/GLSS6_Main\%20Report.pdf accessed 20 June 2016.

Gim, T. H. T. (2013). The relationships between land use measures and travel behavior: a meta-analytic approach. Transportation Planning and Technology, 36(5), 413-434.

Gorham R. (2017) Nigeria. In: Pojani D., Stead D. (eds) The Urban Transport Crisis in Emerging Economies. The Urban Book Series. Springer, Cham

Gough, K. (2010). Continuity and adaptability of home-based enterprises: A longitudinal study from Accra, Ghana. International Development Planning Review, 32(1), 45-70.

Gough, K. V., Tipple, A. G., \& Napier, M. (2003). Making a living in African cities: The role of home-based enterprises in Accra and Pretoria. International Planning Studies, 8(4), 253-277.

Grunfelder, J., Nielsen, T. A., \& Groth, N. B. (2015). Changes to urban form and commuting patterns: trends in two Danish city regions. Geografisk Tidsskrift-Danish Journal of Geography, 115(2), 73-87.

Hall, P. and Pain, K. (2006) The Polycentric Metropolis: Learning from the Mega-city Regions in Europe. London: Earthscan.

Hamed, M. M., \& Olaywah, H. H. (2000). Travel-related decisions by bus, servis taxi, and private car commuters in the city of Amman, Jordan. Cities, 17(1), 63-71

Hincks, S., Kingston, R., Webb, B., \& Wong, C. (2018). A new geodemographic classification of commuting flows for England and Wales. International Journal of Geographical Information Science, 32(4), 663-684.

Hincks, S., \& Wong, C. (2010). The spatial interaction of housing and labour markets: commuting flow analysis of North West England. Urban Studies, 47(3), 620-649.

Lang, R. and Knox, P. K. (2009) The new metropolis: rethinking megalopolis, Regional Studies, 43, pp. 789-802. 
Laan, L. van der (1998) Changing urban systems: an empirical analysis at two spatial levels, Regional Studies, 32, pp. 235-247.

Pinjari, A. R., Pendyala, R. M., Bhat, C. R., \& Waddell, P. A. (2011). Modeling the choice continuum: an integrated model of residential location, auto ownership, bicycle ownership, and commute tour mode choice decisions. Transportation, 38(6), 933-958.

Jain, D., \& Tiwari, G. (2019). Explaining travel behaviour with limited socio-economic data: Case study of Vishakhapatnam, India. Travel Behaviour and Society, 15, 44-53.

Kerkman, Kasper, Karel Martens, and Henk Meurs. "A multilevel spatial interaction model of transit flows incorporating spatial and network autocorrelation." Journal of Transport Geography 60 (2017): 155-166.

Kloosterman, R. C., \& Musterd, S. (2001). The polycentric urban region: towards a research agenda. Urban studies, 38(4), 623-633.

Kutzbach, M. J. (2009). Motorization in developing countries: Causes, consequences, and effectiveness of policy options. Journal of Urban Economics, 65(2), 154-166.

Maat, K., \& Timmermans, H. J. (2009). A causal model relating urban form with daily travel distance through activity/travel decisions. Transportation Planning and Technology, 32(2), 115134.

McNally, M. G. 2000. The activity approach. In Handbook of Transport Modeling, edited by D. A. Hensher, and K. J. Button. Oxford: Pergamon

Manaugh, K., Miranda-Moreno, L. F., \& El-Geneidy, A. M. (2010). The effect of neighbourhood characteristics, accessibility, home-work location, and demographics on commuting distances. Transportation, 37(4), 627-646.

Martínez, L., Viegas, J., \& Silva, E. (2007). Zoning decisions in transport planning and their impact on the precision of results. Transportation Research Record: Journal of the Transportation Research Board, (1994), 58-65.

McFadden, D. (1987). Regression-based specification tests for the multinomial logit model. Journal of econometrics, 34(1-2), 63-82.

Meijers, E. (2008) Measuring polycentricity and its promises, European Planning Studies, 16, pp. 1313-1323.

Moeckel, R., Llorca Garcia, C., Moreno Chou, A. T., \& Okrah, M. B. (2018). Trends in integrated land use/transport modeling: An evaluation of the state of the art. Journal of Transport and Land Use. http://dx.doi.org/10.5198/itlu.2018.1205 
Muñiz, I., Calatayud, D., \& Dobaño, R. (2013). The compensation hypothesis in Barcelona measured through the ecological footprint of mobility and housing. Landscape and Urban Planning, 113, 113-119.

Muñiz, I., \& Garcia-López, M. À. (2019). Urban form and spatial structure as determinants of the ecological footprint of commuting. Transportation Research Part D: Transport and Environment, 67, 334-350.

Naess, P. (2013). Residential location, transport rationales and daily-life travel behaviour: The case of Hangzhou Metropolitan Area, China. Progress in Planning, 79, 5-54.

Næss, P. (2007). The impacts of job and household decentralization on commuting distances and travel modes: Experiences from the Copenhagen region and other Nordic urban areas. Informationen zur Raumentwicklung, 2(3), 149-168.

Paulssen, M., Temme, D., Vij, A., \& Walker, J. L. (2014). Values, attitudes and travel behavior: a hierarchical latent variable mixed logit model of travel mode choice. Transportation, 41(4), 873888.

Rasouli, S., \& Timmermans, H. (2014). Applications of theories and models of choice and decision-making under conditions of uncertainty in travel behavior research. Travel Behaviour and Society, 1(3), 79-90

Sarkar, S., Wu, H., \& Levinson, D. (2018). Measuring polycentricity via network flows, spatial interaction, and percolation. Working Paper Working http://hdl.handle.net/2123/18792

Schwanen, T., Dieleman, F. M., \& Dijst, M. (2001). Travel behaviour in Dutch monocentric and policentric urban systems. Journal of Transport Geography, 9(3), 173-186.

Sietchiping, R., Permezel, M. J., \& Ngomsi, C. (2012). Transport and mobility in sub-Saharan African cities: An overview of practices, lessons and options for improvements. Cities, 29(3), 183-189.

Stow, D. A., Weeks, J. R., Toure, S., Coulter, L. L., Lippitt, C. D., \& Ashcroft, E. (2013). Urban vegetation cover and vegetation change in Accra, Ghana: Connection to housing quality. The Professional Geographer, 65(3), 451-465.

Taylor, P. J., Evans, D. M. and Pain, K. (2006) Organization of the polycentric metropolis: corporate structures and networks, in: P. Hall and K. Pain (Eds) The Polycentric Metropolis: Learning from the Mega-city Regions in Europe, pp. 53-64. London: Earthscan 
van Eck, J. R., Burghouwt, G., \& Dijst, M. (2005). Lifestyles, spatial configurations and quality of life in daily travel: an explorative simulation study. Journal of Transport Geography, 13(2), 123134.

Vasanen, A. (2012). Functional polycentricity: examining metropolitan spatial structure through the connectivity of urban sub-centres. Urban studies, 49(16), 3627-3644.

Venter, C., Vokolkova, V., \& Michalek, J. (2007). Gender, residential location, and household travel: Empirical findings from low-income urban settlements in Durban, South Africa. Transport Reviews, 27(6), 653-677.

Vij, A., Carrel, A., \& Walker, J. L. (2013). Incorporating the influence of latent modal preferences on travel mode choice behavior. Transportation Research Part A: Policy and Practice, 54, 164178.

Wang, D., Chai, Y., \& Li, F. (2011). Built environment diversities and activity-travel behaviour variations in Beijing, China. Journal of Transport Geography, 19(6), 1173-1186.

Wegener, M., and Fürst, F. (2004). Land-use transport interaction: state of the art. Url: http://econwpa.repec.org/eps/urb/papers/0409/0409005.pdf. [Accessed 28th September 2014]

Yang, W., \& Cao, X. (2018). Examining the effects of the neighbourhood built environment on CO2 emissions from different residential trip purposes: A case study in Guangzhou, China. Cities https://doi.org/10.1016/i.cities.2018.03.009

Yang, J., \& Ferreira Jr, J. (2008). Choices versus choice sets: A commuting spectrum method for representing job - Housing possibilities. Environment and Planning B: Planning and Design, 35(2), 364-378.

Yue, W., Liu, Y. and Fan, P. (2010) Polycentric urban development: the case of Hangzhou, Environment and Planning A, 42, pp. 563-577.

Zhang, S., Liu, X., Tang, J., Cheng, S., \& Wang, Y. (2019). Urban spatial structure and travel patterns: Analysis of workday and holiday travel using inhomogeneous Poisson point process models. Computers, Environment and Urban Systems, 73, 68-84.

Zhang, Y., Wang, X., Zeng, P., \& Chen, X. (2011). Centrality characteristics of road network patterns of traffic analysis zones. Transportation Research Record: Journal of the Transportation Research Board, (2256), 16-24.

Zhao, P., Lu, B., \& de Roo, G. (2011). The impact of urban growth on commuting patterns in a restructuring city: Evidence from Beijing. Papers in Regional Science, 90(4), 735-754. 
Zhao, P. (2010). Sustainable urban expansion and transportation in a growing megacity: Consequences of urban sprawl for mobility on the urban fringe of Beijing. Habitat International, 34(2), 236-243.

Zhong, C., Schläpfer, M., Müller Arisona, S., Batty, M., Ratti, C., \& Schmitt, G. (2017). Revealing centrality in the spatial structure of cities from human activity patterns. Urban Studies, 54(2), 437-455. 